\title{
USING HISTORICAL AERIAL PHOTOGRAPHY AND SOFTCOPY PHOTOGRAMMETRY FOR WASTE UNIT MAPPING IN L LAKE
}

Aiken, South Carolina

\author{
RECEIVED \\ NOV 0.71997 \\ OSTI
}

\section{9}

\section{MASTER}

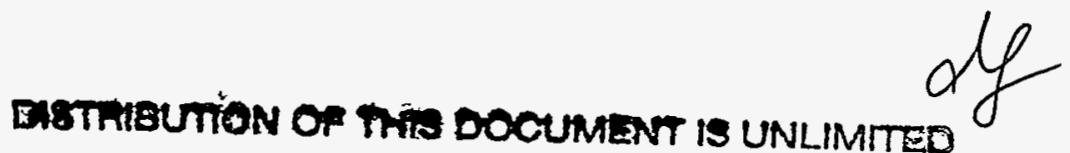




\section{DISCLAIMER}

This report was prepared as an account of work sponsored by an agency of the United States government. Neither the United States government nor an agency thereof, or any of their employees, makes a warranty, express or implied, or assumes legal liability or responsibility for the accuracy, completeness, or usefulness of any disclosed information, apparatus, product, or process, or represents that its use would not infringe privately owned rights. Reference herein to a specific commercial product, process, or service by trade name, trademark, manufacturer, or otherwise does not necessarily constitute or imply an endorsement, recommendation, or favoring by the United States government or an agency thereof. The views and opinions of the authors expressed herein do not necessarily state or reflect those of the United States government or an agency thereof.

This report has been reproduced directly from the best available copy.

This report is available to DOE and DOE contractors from the Office of Scientific and Technical Information, P.O. Box 62, Oak Ridge, TN 37831. Call (423) 576-8401 to obtain prices.

This report is available to the public from the National Technical Information Service, U.S. Department of Commerce, 5285 Port Royal, Springfield, VA 22161. Call (703) 487-4650 for information. 


\section{DISCLAIMER}

Portions of this document may be illegible electronic image products. Images are produced from the best available original document. 


\section{USING HISTORICAL AERIAL PHOTOGRAPHY AND SOFTCOPY PHOTOGRAMMETRY FOR WASTE UNIT MAPPING IN L LAKE}

Aiken, South Carolina

L. M. Christel

Project Scientist

REVIEWED BY

J. D. Blohm

Data Fusion and Analysis
L. M. Christel

SRS Project Manager

This Document is UNCLASSIFIED

C. L. Rivera
Authorized Derivative Classifier

This work was performed by Bechtel Nevada under Contract Number DE-AC08-96NV11718 with joint funding provided by the U.S. Department of Energy and Westinghouse Savannah River Company, Inc., operators of the Savannah River Site and Savannah River Technology Center. 


\begin{abstract}
L Lake was developed as a cooling water reservoir for the $L$ Reactor at the Savannah River Site. The construction of the lake, which began in the fall of 1984, altered the structure and function of Steel Creek. Completed in the fall of $1985, \mathrm{~L}$ Lake has a capacity of 31 million cubic meters and a normal pool of 58 meters. When L Reactor operations ceased in 1988, the water level in the lake still had to be maintained. Site managers are currently trying to determine the feasibility of draining or drawing down the lake in order to save tax dollars.

In order to understand the full repercussions of such an undertaking, it was necessary to compile a comprehensive inventory of what the lake bottom looked like prior to filling. Aerial photographs, acquired nine days before the filling of the lake began, were scanned and used for softcopy photogrammetry processing. A one-meter digital elevation model was generated and a digital orthophoto mosaic was created as the basemap for the project. Seven categories of features, including the large waste units used to contain the contaminated soil removed from the dam site, were screen digitized and used to generate accurate maps. Other map features include vegetation waste piles, where contaminated vegetation from the flood plain was contained, and ash piles, which are sites where vegetation debris was burned and then covered with clean soil. For all seven categories, the area of disturbance totaled just over 63 hectares.

When the screen digitizing was completed, the elevation at the centroid of each disturbance was determined. When the information is used in the Savannah River Site Geographical Information System, it can be used to visualize the various $L$ Lake draw-down scenarios suggested by site managers and hopefully, to support evaluations of the cost effectiveness for each proposed activity.
\end{abstract}




\section{CONTENTS}

Abstract

\section{Sections}

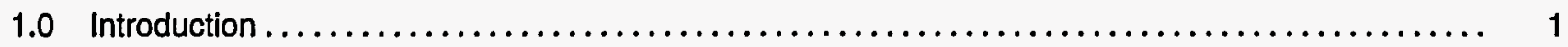

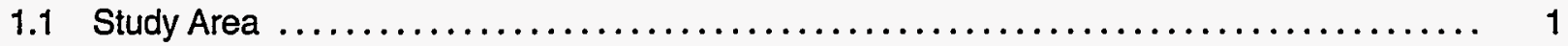

1.2 Steel Creek and $L$ Reactor History $\ldots \ldots \ldots \ldots \ldots \ldots \ldots \ldots \ldots \ldots \ldots \ldots \ldots \ldots \ldots \ldots \ldots \ldots \ldots \ldots \ldots \ldots$

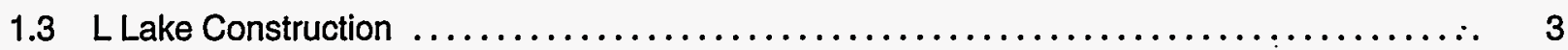

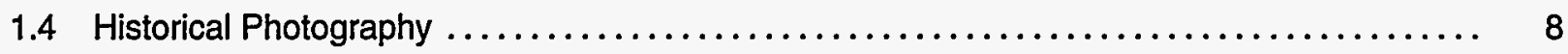

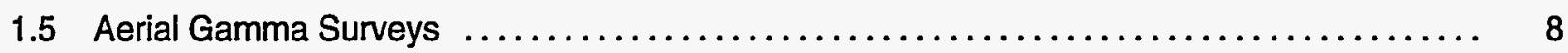

2.0 Softcopy Photogrammetry Orthophoto Process $\ldots \ldots \ldots \ldots \ldots \ldots \ldots \ldots \ldots \ldots \ldots \ldots \ldots \ldots \ldots$

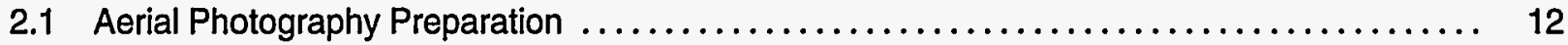

2.2 Project Definition and Processing $\ldots \ldots \ldots \ldots \ldots \ldots \ldots \ldots \ldots \ldots \ldots \ldots \ldots \ldots \ldots \ldots \ldots \ldots \ldots \ldots \ldots \ldots$

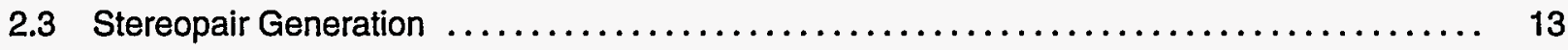

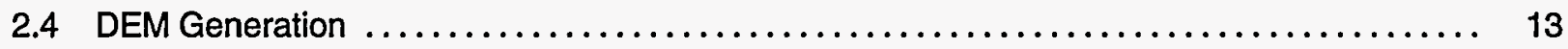

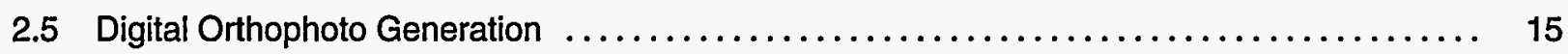

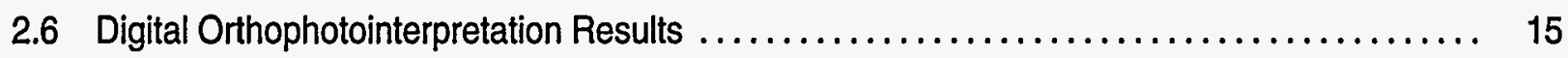

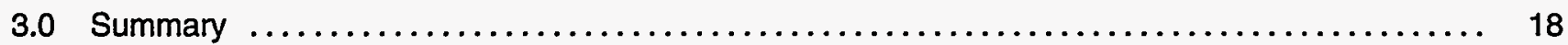

\section{Figures}

$1 \quad$ Inset on the Left Shows the Reach of L Lake and Steel Creek at SRS

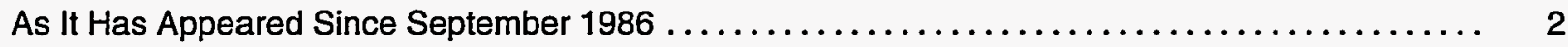

2 Upper Reach of Steel Creek Prior to Development $\ldots \ldots \ldots \ldots \ldots \ldots \ldots \ldots \ldots \ldots \ldots \ldots \ldots \ldots$

3 Before and After Construction Views of the Dam and Waste Burial Units $\ldots \ldots \ldots \ldots \ldots \ldots \ldots$

4 Close Examination of the Stream Channel Shows That a Majority of Vegetation

Was Removed from the Upper Portions of the Channel, but Vegetation was Left

Standing in the Lower Third of the Basin, Just North of the Dam .................... 7

5 Vegetation Debris (top), Concrete Blocks (lower right), and Anchored Tree Trunks (lower left) Were Used to Facilitate Habitat Development in L Lake $\ldots \ldots \ldots \ldots \ldots \ldots \ldots \ldots \ldots 9$

6 Dose-Rate Contours of ${ }^{137} \mathrm{Cs}$ Indicate That the Area Around the Dam Site Showed No Evidence of Radiological Activity

7 This Photographic Time Series Shows the Transition from Standing Vegetation in the Upper Left to Soil-Covered Vegetation Ash Piles in the Lower Right 
8 Level-Sliced DEM Showing Elevation Ranges .

9 Mosaicked Digital Orthophotograph of the L Lake Basin Derived

from Five Separate Photographs

10 Seven Types of Features of Interest Were Interpreted from the

Digital Orthophotograph

11 Vector Layers Digitized from-Engineering Plans Overlayed on the

Digital Orthophotograph .

\section{Tables}

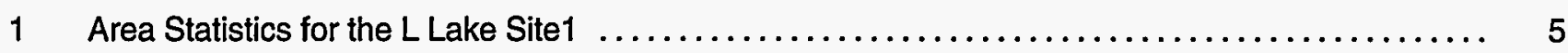

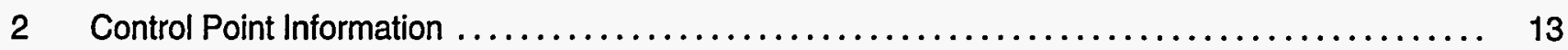

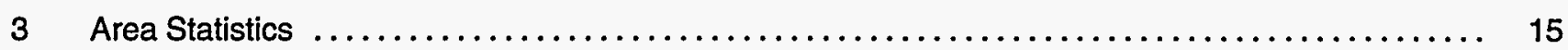

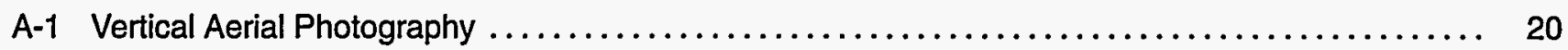

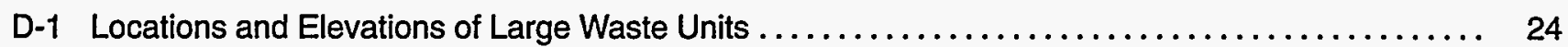

D-2 Locations and Elevations of Vegetation Waste Units $\ldots \ldots \ldots \ldots \ldots \ldots \ldots \ldots \ldots \ldots \ldots \ldots \ldots \ldots \ldots$

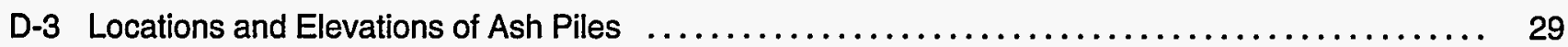

D-4 Locations and Elevations of Potential Waste Units $\ldots \ldots \ldots \ldots \ldots \ldots \ldots \ldots \ldots \ldots \ldots \ldots \ldots$

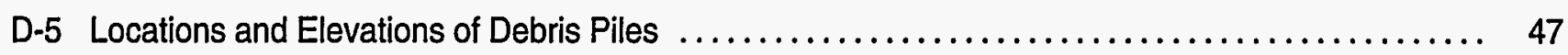

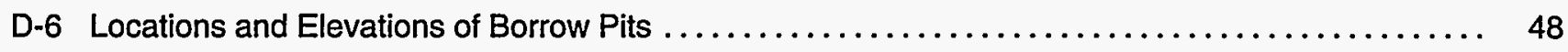

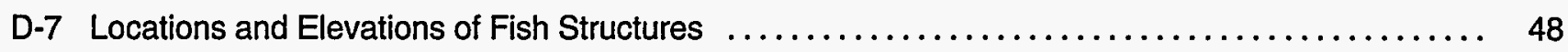

\section{Appendices}

A Vertical Aerial Photography Used for Photointerpretation and Mapping $\ldots \ldots \ldots \ldots \ldots \ldots \ldots .20$

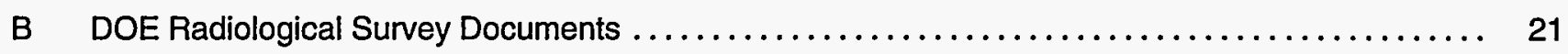

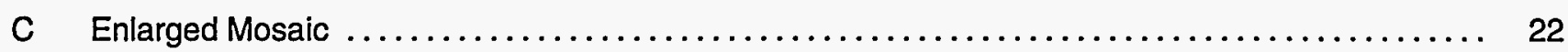

D Locations and Elevations of Photointerpretated Map Features $\ldots \ldots \ldots \ldots \ldots \ldots \ldots \ldots \ldots \ldots$

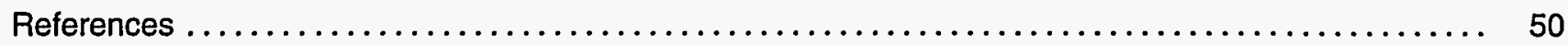




\subsection{Introduction}

Since 1988 when L Reactor operations ceased, the water level in its cooling water reservoir, L Lake, has been artificially maintained at a high annual cost. Recent discussions about lowering or completely draining the lake to cut costs and save tax dollars led to a study where the bottom features of $L$ Lake were mapped to assess the feasibility of lowering or draining the water. The existence of contaminated waste units and debris piles in the lake bottom are known and were photographically documented before the lake-was. filled. This study relied on available oblique and vertical aerial photography acquired throughout the development of the lake. Additional ground photography, engineering as-built plans, and relevant reports also served as important sources of information during the process of mapping the lake bottom as it appeared nine days before filling began.

The main purpose of the study was to generate geographically accurate digital orthophotography as baseline imagery for input into a Geographic Information System (GIS). Digital photointerpretation techniques were then used to derive layers of information that can be used to accurately map the L Lake basin. In the process, a digital elevation model (DEM) was generated. The elevation information offered by this data set is intended to support efforts to estimate and model the exposed areas of potentially contaminated sites at any given water level. The GIS can be used for estimating the time and cost expenditures required for various draw-down and clean-up scenarios.

This report includes a description of the reservoir and its history, outlines the preplanning efforts for the study, and provides an overview of the processes used to generate the DEM and digital orthophotography. The last section of the report discusses the digital photointerpretation methods and results. Additional information regarding radiological studies, the vertical aerial photography used in the study, and area statistics for the mapped lake-bottom features is included in the appendices.

\subsection{Study Area}

This study was conducted on the portion of Steel Creek on the Savannah River Site (SRS) (formerly known as the Savannah River Plant [SRP] prior to 1989) in South Carolina, which was converted to L Lake in 1984-1985. The SRS lies on the upper Atlantic Coastal Plain and was established in the early 1950 s by the U.S. government for the production of special nuclear materials, primarily to support the nuclear weapons program of the United States. Steel Creek is one of five major drainages on the SRS. This stream rises in the Aiken Plateau and flows approximately 18 kilometers south to the Savannah River floodplain that bounds the southern portion of the SRS. Steel Creek then flows approximately 4 kilometers through the Savannah River floodplain before entering the Savannah River. Figure 1 shows the locations of $L$ Lake and Steel Creek as well as two production reactors located at the SRS.

\subsection{Steel Creek and L Reactor History}

Steel Creek is 18 kilometers in length and has a watershed of 90 square kilometers. From 1955 to 1973 , approximately 284 curies of cesium-137 ( $\left.{ }^{137} \mathrm{Cs}\right)$ were released into Steel Creek. Because ${ }^{137} \mathrm{Cs}$ has a strong affinity for sediments, a majority of the released material was absorbed and/or deposited in the sediments of the Steel Creek system before they reached the Savannah River. An estimate of the inventory of ${ }^{137} \mathrm{Cs}$ in Steel Creek, as decay corrected to 1991, lists 8 curies upstream from L Reactor, 30 curies between L Reactor and the Steel Creek Delta, 20 curies in the Steel Creek Delta, and 


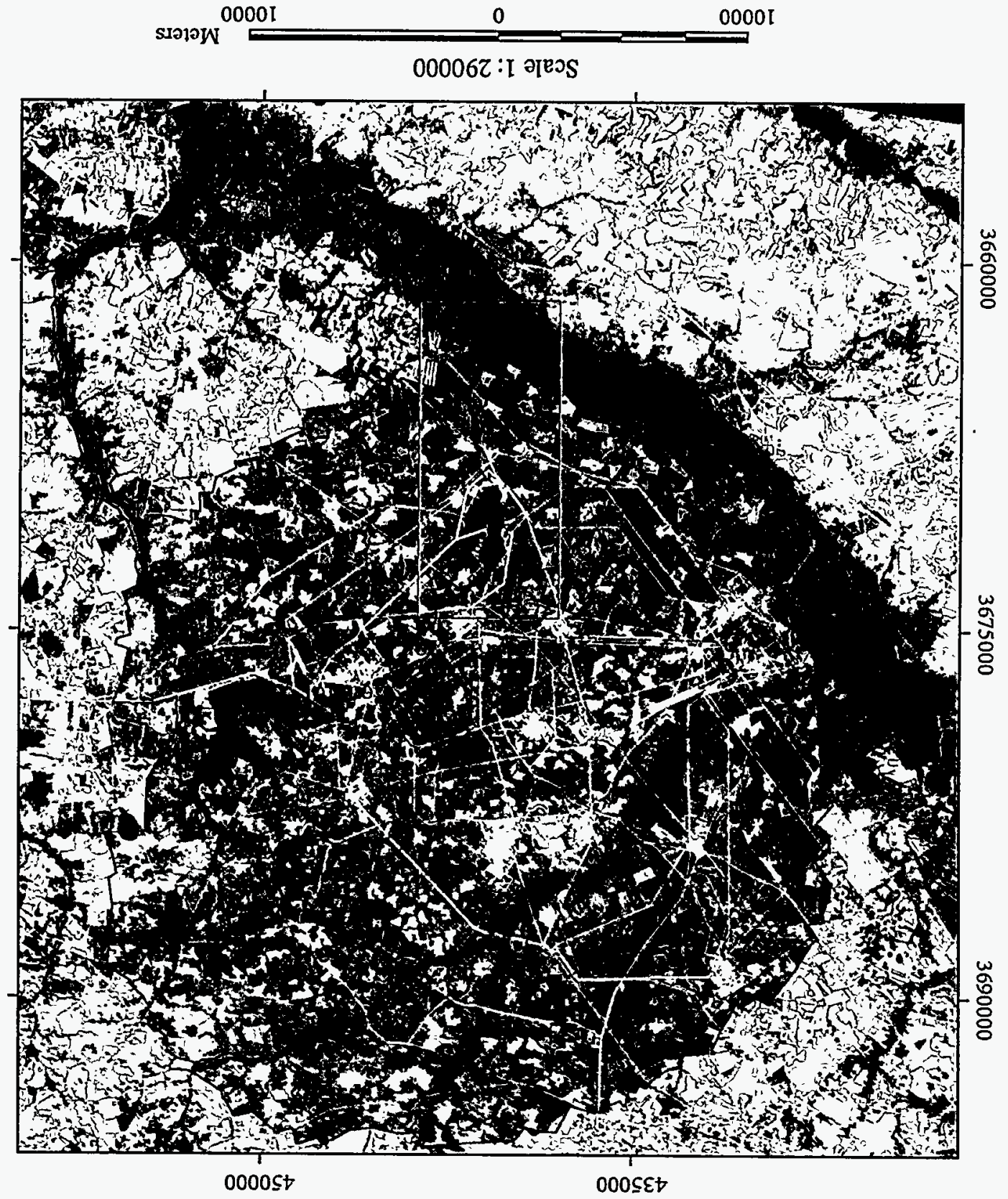

$\underset{\angle Z G \forall N \text { umpa }}{\angle I \text { OUOZ WLI }}$

0000II:I ə|e्S 1อsuI

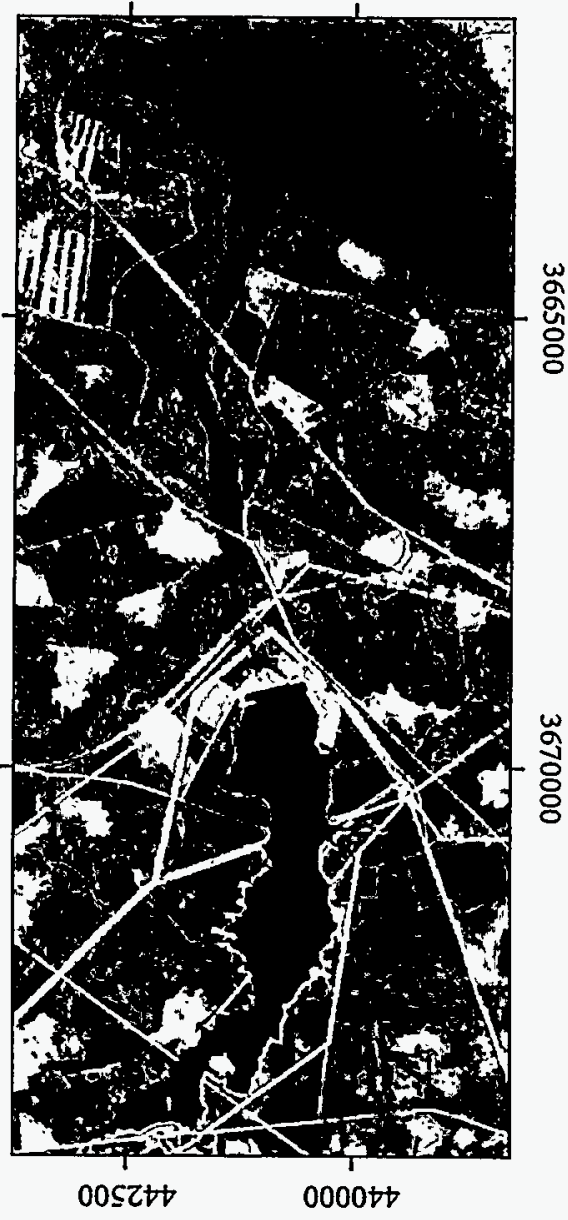


8 curies between the delta and the SRS boundary for a total of 66 curies in the Steel Creek system (Brisbin et al., 1974; Gladden et al., 1985; Carlton et al., 1992). Cobalt-60 ( ${ }^{60} \mathrm{Co}$ ) discharges to Steel Creek are summarized in Carlton and Denham, 1996.

Operations of the $P$ and $L$ Reactors began in 1954. Stream discharge in Steel Creek was increased from about 1 cubic meter per second to a maximum of 24 cubic meters per second with secondary cooling water effluent pumped from the Savannah River. This secondary cooling water was released at temperatures as high as $70^{\circ} \mathrm{C}$ to the streams of the SRS. These two reactors in the headwaters of Steel Creek greatly affected the hydrologic and thermal regimes of the stream. The results of the increased stream flow in Steel Creek included the inundation of the floodplain along the length of Steel Creek, erosion, loss of the original wetland plant communities, and deposition of radioactive contamination (Gladden et al., 1985). Cooling water effluent from P Reactor was diverted to Par Pond in 1963, and a more normal (near natural) flow regime was reestablished in 1968 when L Reactor was placed on standby.

Refurbishment of $L$ Reactor began in the early 1980 s with plans to restart in 1985 . With the cessation of thermal releases to Steel Creek, scrub-shrub and persistent and nonpersistent emergent plant communities colonized the Steel Creek floodplain and were in place when L Lake was constructed during 1984-1985 (Wein and McCort, 1988; Tinney et al., 1987). The upland areas of L Lake had been managed largely as sustained-yield pine plantations by the U.S. Forest Service for the Department of Energy (DOE) (Tinney et al., 1987). To provide thermal mitigation of secondary cooling water from the restart of $L$ Reactor, $L$ Lake was constructed by damming the middle reach of Steel Creek. $L$ Reactor was restarted in the fall of 1985 , following dam construction and lake filling, and continued operating until it was shut down in 1988.

\subsection{Lake Construction}

In February 1984, the U.S. Army Corps of Engineers was given the responsibility through an interagency agreement with the DOE for designing and constructing a once-through cooling water reservoir, $L$ Lake. The construction of $L$ Lake altered the structure and function of the upper to middle portions of about one-third of Steel Creek from a riverine to a lacustrine ecosystem. The portion of Steel Creek affected by construction is shown in Figure 2. Construction of $L$ Lake began in the fall of 1984, and L Lake was formed by damming the middle reach of Steel Creek between SRS Road B and Highway 125 . The 405 -hectare $L$ Lake has a capacity of 31 million cubic meters and is 7000 meters long and 1200 meters wide at its widest point (average 600 meters). The dam, located at the southern end of the lake, is 1200 meters long. The normal pool of the lake is 58 meters above mean sea level (MSL). The top of the main embankment of the L Lake dam is 61 meters above MSL (Gladden et al., 1989). Clear-cuts made during construction of the lake totaled 418 hectares including 144 hectares of bottomland hardwood and shrub wetlands, 146 hectares of upland hardwood and pine forest, and 50 hectares of other areas within the lake basin (Wein and McCort, 1988; Wein and Pierce, 1995). Estimates of land-cover types within L Lake proper were estimated in Ezra and Tinney, 1985, and are shown in Table 1. Timber growing above the floodplain of Steel Creek was cut for commercial sale. Outside of the lake basin, 78 hectares of mostly upland pine (approximately 60 hectares) and hardwood forests (approximately 18 hectares) were clear-cut for power-line right-of-ways and other construction-related activities (McCort et al., 1988). 


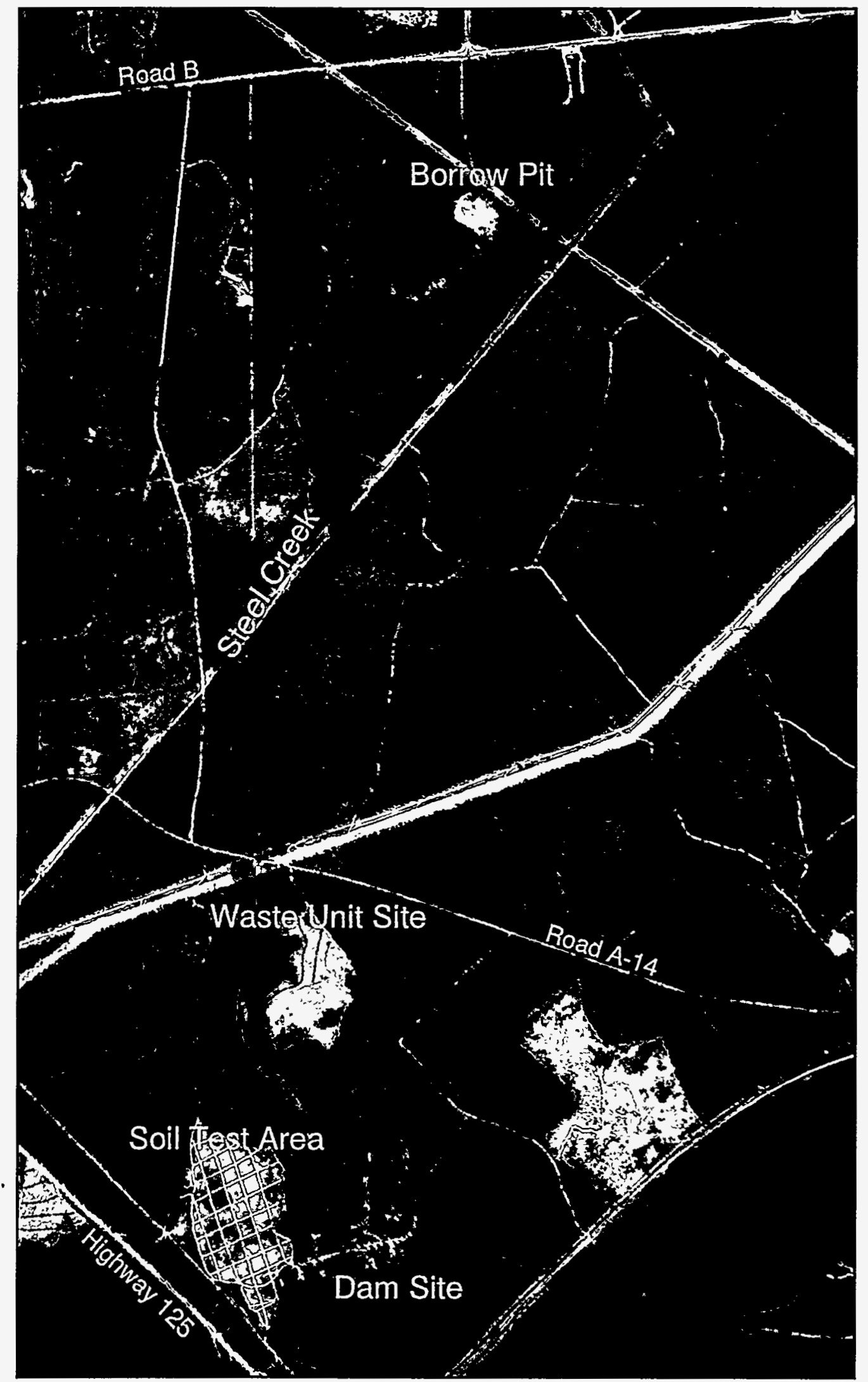

Source: EG\&G 4655-006 acquired 3-31-84 at scale 1:34400.<smiles>C[C+]1CC1C</smiles>

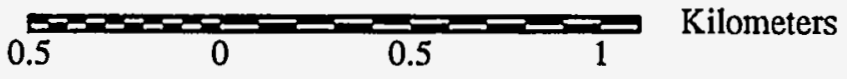

FIGURE 2. UPPER REACH OF STEEL CREEK PRIOR TO DEVELOPMENT. An existing borrow pit, the antlcipated waste disposal unit, and the area where soll tests were performed to determine the adequacy of local material for construction use are shown. 


\begin{tabular}{|c|c|c|}
\hline Class & Hectares & $\begin{array}{l}\text { Site } \\
\text { Percent }\end{array}$ \\
\hline Water & 0.7 & 0.2 \\
\hline Nonpersistent Emergent & 0.5 & 0.1 \\
\hline Scrub-Shrub & 28.9 & 6.9 \\
\hline Bottomland Hardwood & 109.5 & 26.0 \\
\hline Deciduous Forest & 4.8 & 1.1 \\
\hline Evergreen Forest & 114.2 & 27.0 \\
\hline Clear-Cut & 0.4 & 0.1 \\
\hline Mixed Forest & 124.9 & 29.6 \\
\hline Transitional & 8.1 & 1.9 \\
\hline Industrial & 1.7 & 0.4 \\
\hline Utilities & 20.7 & 4.9 \\
\hline Roads & 7.4 & 1.8 \\
\hline Total & $\overline{421.8}$ & 100.0 \\
\hline
\end{tabular}

a Source: Ezra and Tinney, 1985

During the construction of $L$ Lake dam, dredged spoil from the floodplain of Steel Creek at the dam site was placed in a special waste disposal area, allowed to dry, leveled, and then covered with 1.5 meters of soil (Zeigler et al., 1985). The area of the waste disposal site for the L Lake dam was estimated to be at least 5 hectares based on earlier interpretation of digitized non-georeferenced aerial photography from September 1985. Figure 3 shows the changes that occurred at the dam and waste burial sites between March 1984 and September 1985. Approximately 46,400 cubic meters of spoil material were removed from the dam site.

Although only the upper 1.2 meters of streambed material was considered to be radioactively contaminated, the streambed was excavated to a depth of about 3 meters (Gladden et al., 1989). This spoil material was estimated to contain 0.2 curies of ${ }^{137} \mathrm{Cs}$ and 0.02 curies of ${ }^{60} \mathrm{Co}$ (Zeigler et al., 1985). This buried spoil material was flooded over when the lake was filled (DOE, 1984).

Trees outside of the Steel Creek floodplain were sold through commercial timber harvests managed by the U.S. Forest Service. Trees within the floodplain were potentially contaminated from the radioisotopes in the soils (Gladden et al., 1985; Briese et al., 1975; Brisbin et al., 1974). Vegetation growing in the floodplain area of Steel Creek covered by the lake was estimated to contain about 12 millicuries of ${ }^{137} \mathrm{Cs}$ (Zeigler et al., 1985). Figure 4 shows that the woody vegetation in the Steel Creek floodplain was removed from the upper two-thirds of $L$ Lake but was left standing in the lower one-third of the floodplain immediately upstream of the cofferdam used during construction of the L Lake dam (Dunn et al., 1995).

Before L Lake was filled, 35 artificial reefs including 3 log reefs, 7 brush reefs, 12 tire reefs, 12 concrete block reefs, and 1 floating tire breakwater were constructed. The reefs were constructed to provide habitat diversity and structure in the lake before an aquatic plant community was established (Gladden 


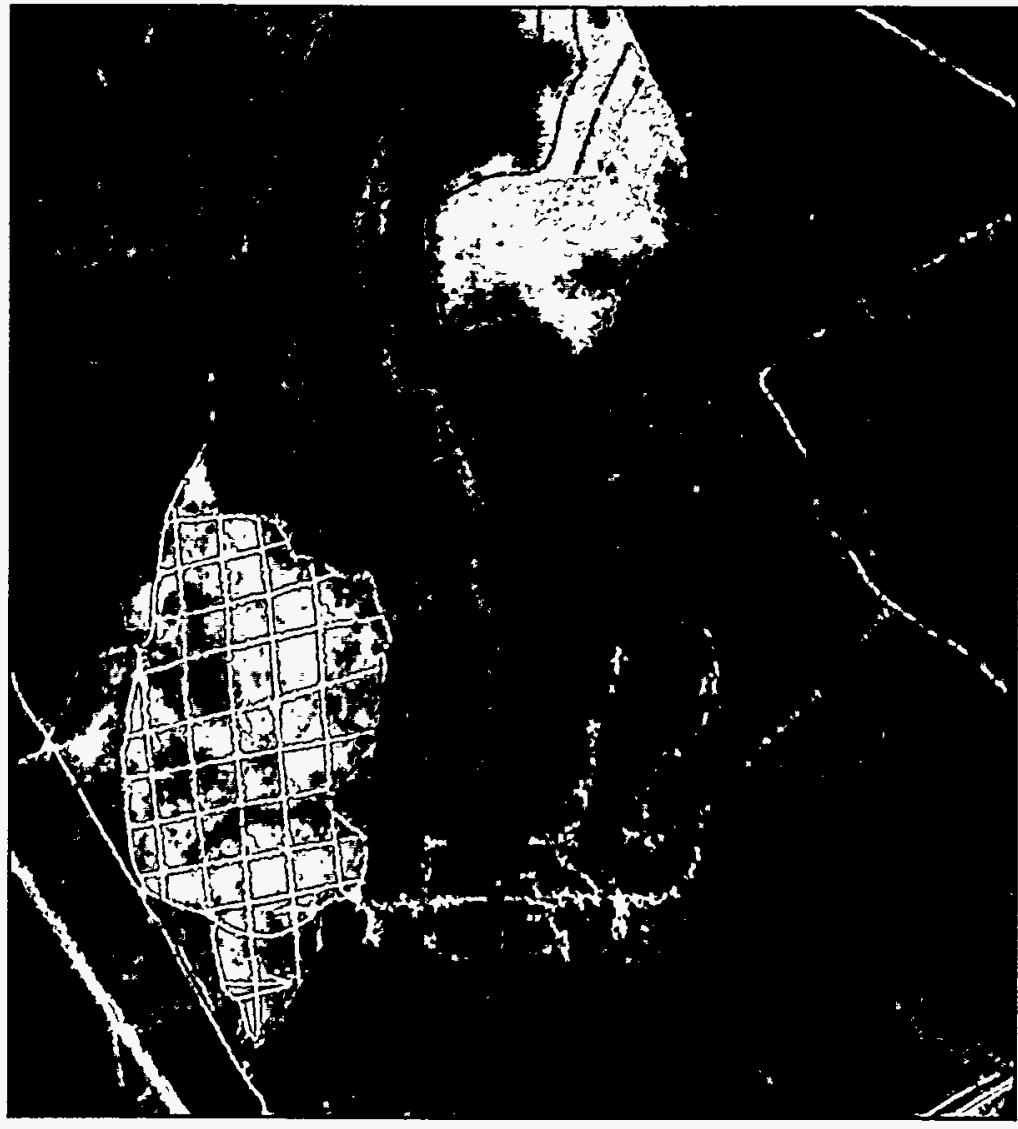

Source: EG\&G 4655-006 acquired 3-31-84 at scale 1:34400

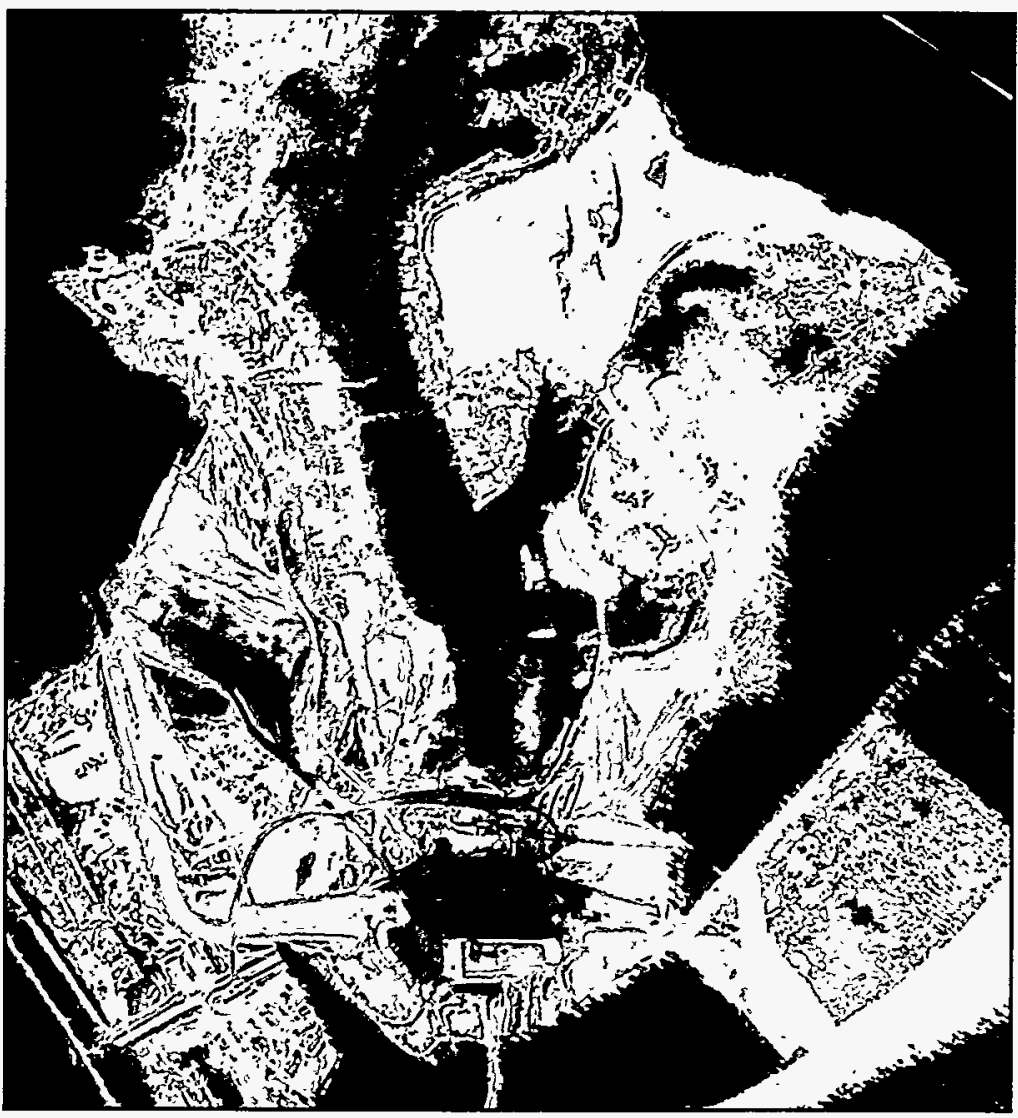

Source: EG\&G 5108-094 acquired 9-6-85 at scale 1:13900

FIGURE 3. BEFOREANDAFTER CONSTRUCTION VIEWSOFTHEDAMAND WASTEBURIAL UNITS:The clay-coloredmaterials to the upper left of the dam are belleved to be either source materials for dam construction or potential waste units. 


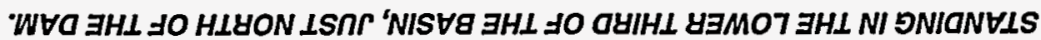
Lงヨ7S

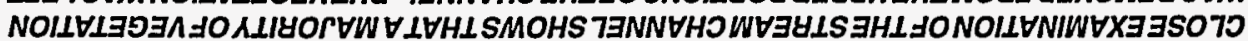

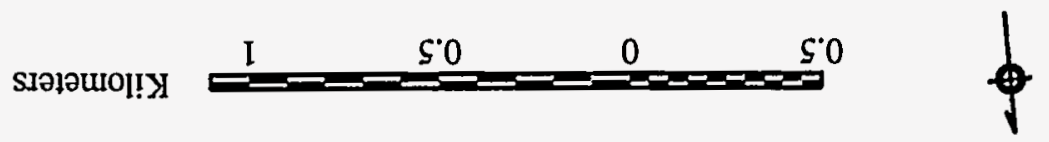

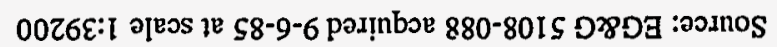

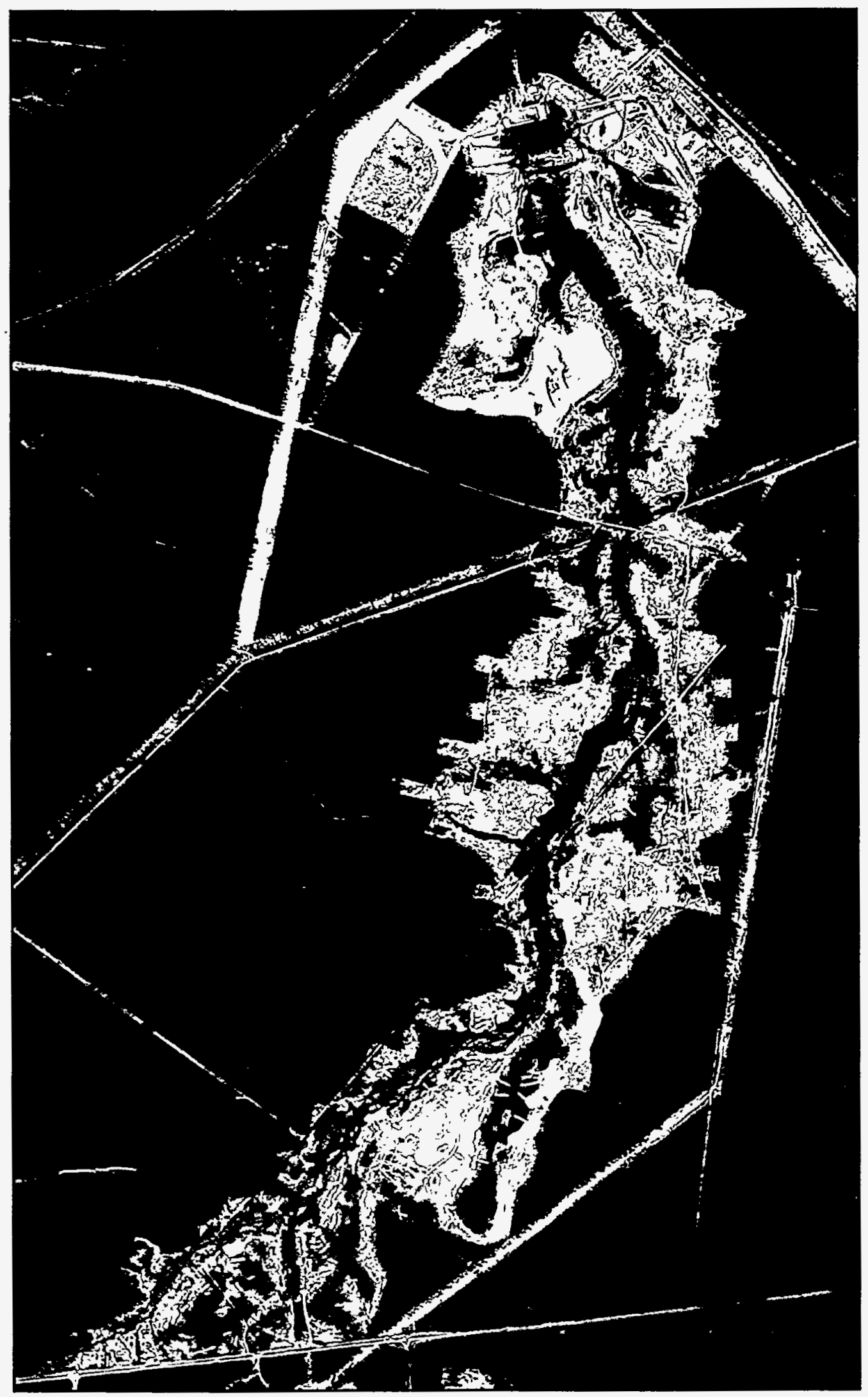


et al., 1989). Several of these structures, shown in Figure 5, are evident in the aerial photography used in this report. The filling of $L$ Lake began on September 15, 1985, and the lake reached a normal operating level of 58 meters above MSL on November 4, 1985 (Gladden et al., 1989).

During the summer of 1986 , a riprap diversion dike and canal were constructed in the northern end of $L$ Lake just south of the SRS Road B to more effectively use the cooling capacity of the lake. The canal diverted the $L$ Reactor effluent from the original discharge point in $L$ Lake east to a point nearer the head of the lake. Surveying for the dike and canal began in July 1986 and construction was completed in September 1986 (Gladden et al., 1989). Changes in the configuration of L Lake caused by the construction of the dike and canal are not included in this report.

\subsection{Historical Photography}

A review of historical photography available from the DOE Remote Sensing Laboratory (RSL) indicated that several aerial acquisitions of Steel Creek had occurred during 1984-1985. Pre-construction dates, when the presence of test drillings near the future dam site and an existing borrow pit in the upper portion of the lake were visually documented, include March 31, April 1, June 18, and September 19,1984 . The archeological pit is also visible in the photography. Construction began in the fall of 1984. Aerial photography of the Steel Creek conversion was acquired on the following dates: April 17, April 25, May 14, May 18-19, June 21, and September 6, 1985. Refer to Appendix A for details about these photographs. Based on the information in the photography, material appears to have been removed from the base of the dam within the Steel Creek floodplain and deposited in a large pit north of the dam site and east of the Steel Creek floodplain. Note that in the August 13-23, 1985 aerial gamma survey report of the Steel Creek floodplain, no ${ }^{137} \mathrm{Cs}$ activity is shown in close proximity to the L Lake dam construction site or to the likely area for the waste disposal site (Jobst, 1988). The distribution of ${ }^{137} \mathrm{Cs}$ is illustrated in Figure 6.

Commercial timber harvesting was widespread throughout the upland areas, or non-floodplain areas of the future lake bed. Following the tree harvest, the remaining debris appears to have been placed in piles and then burned. Debris and ash piles are visible in the photography shown in Figure 7. The ash piles, which are characteristically oval-shaped, were covered with local soil materials and numbered to several hundred.

The time sequence of photography shows that after the upland areas were harvested, the floodplain was cleared of timber and a series of disturbances occurred lateral to or within the floodplain. This activity began in the northern portion of the lake bed and continued southward. These features appear at irregular intervals and are thought to be the locations of contaminated materials removed from the floodplain. They are less well-defined in shape and appear to "cast a shadow," which indicates that they may be "mound-like." It is estimated that there are more than 150 mounds; some may not have been used, especially in the lower one-third of the lake. The last date of RSL photographic coverage is September 6, 1985. Aerial photography acquired after September 1985 shows the lake at full pool.

\subsection{Aerial Gamma Surveys}

Numerous radiological surveys of the Steel $C r e e k$ and $L$ Lake area have been performed. For detailed information on the gamma activity within the Steel Creek drainage prior to L Lake construction, refer to the DOE documents listed in Appendix B. 


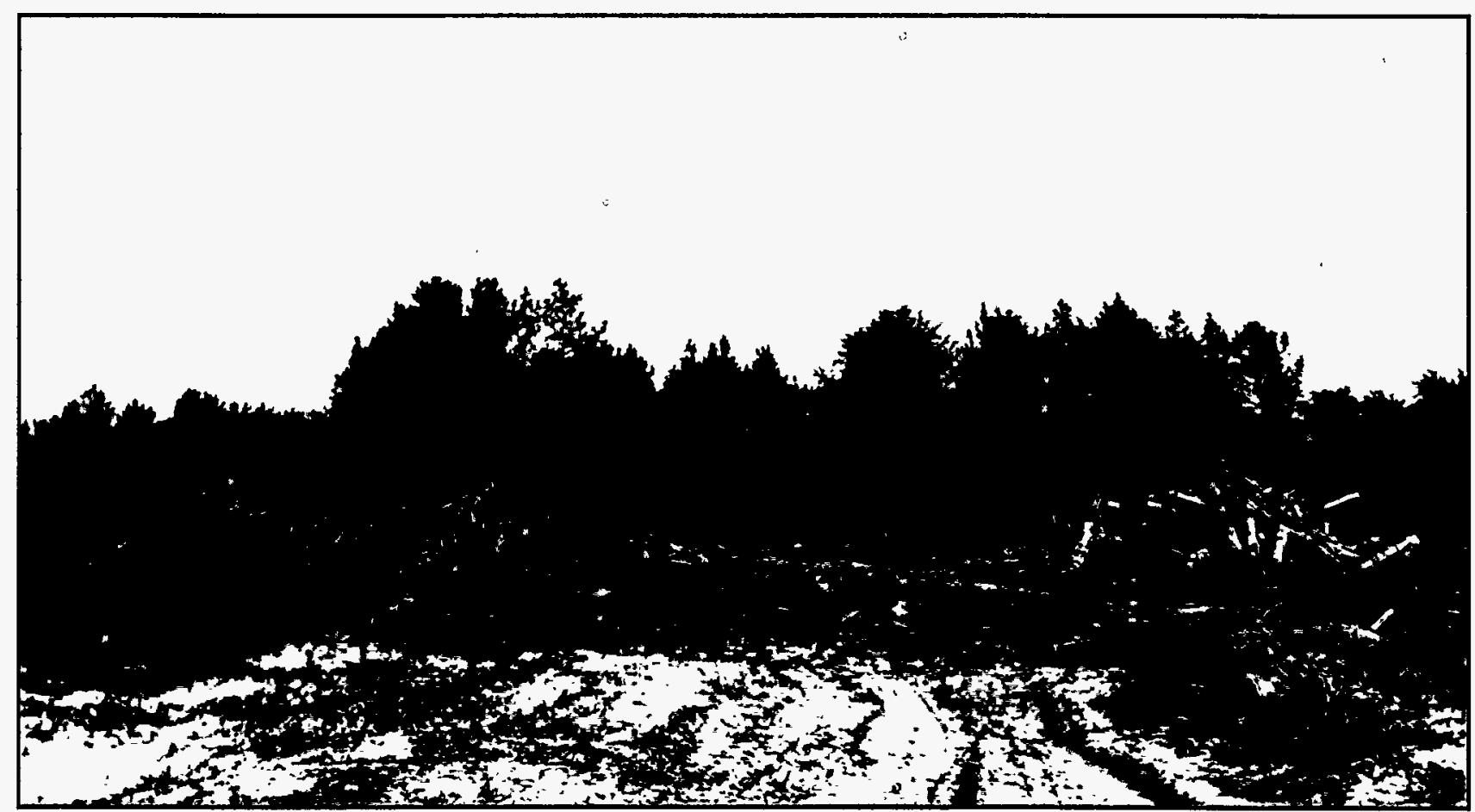

Source photograph 42479-6 courtesy of SRS.

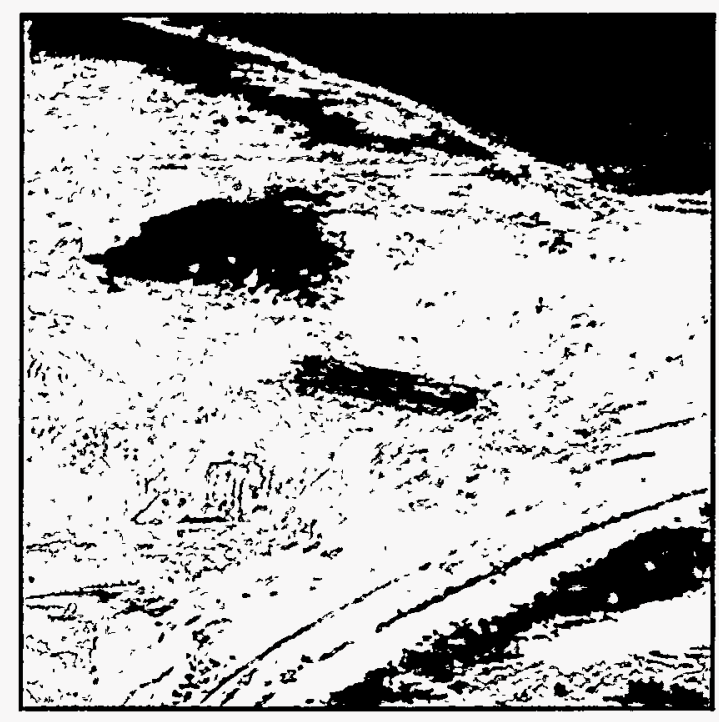

Source photograph 5076-16 courtesy of SRS.

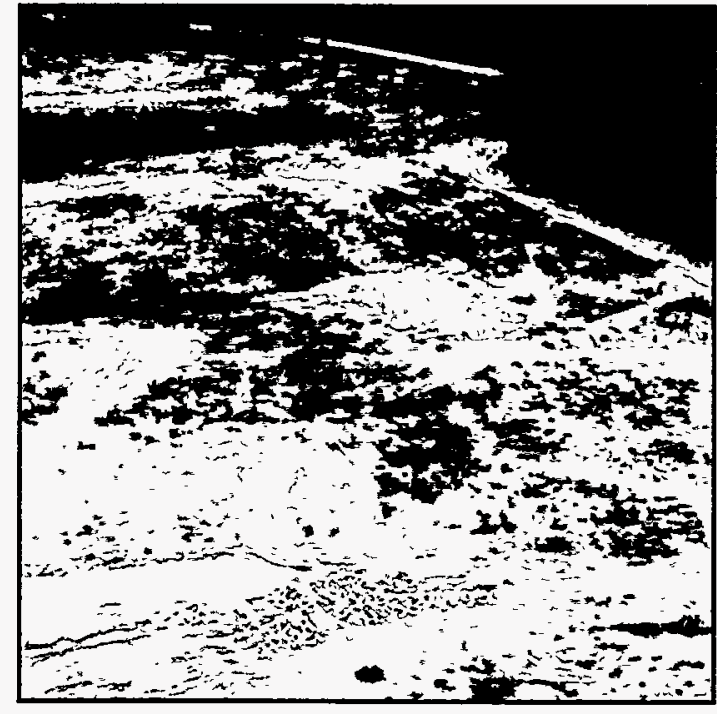

Source photograph 5076-05 courtesy of SRS.

FIGURE 5. VEGETATION DEBRIS (TOP), CONCRETE BLOCKS (LOWER RIGHT), AND ANCHORED TREE TRUNKS (LOWER LEFT) WERE USED TO FACILITATE HABITAT DEVELOPMENT IN L LAKE. 


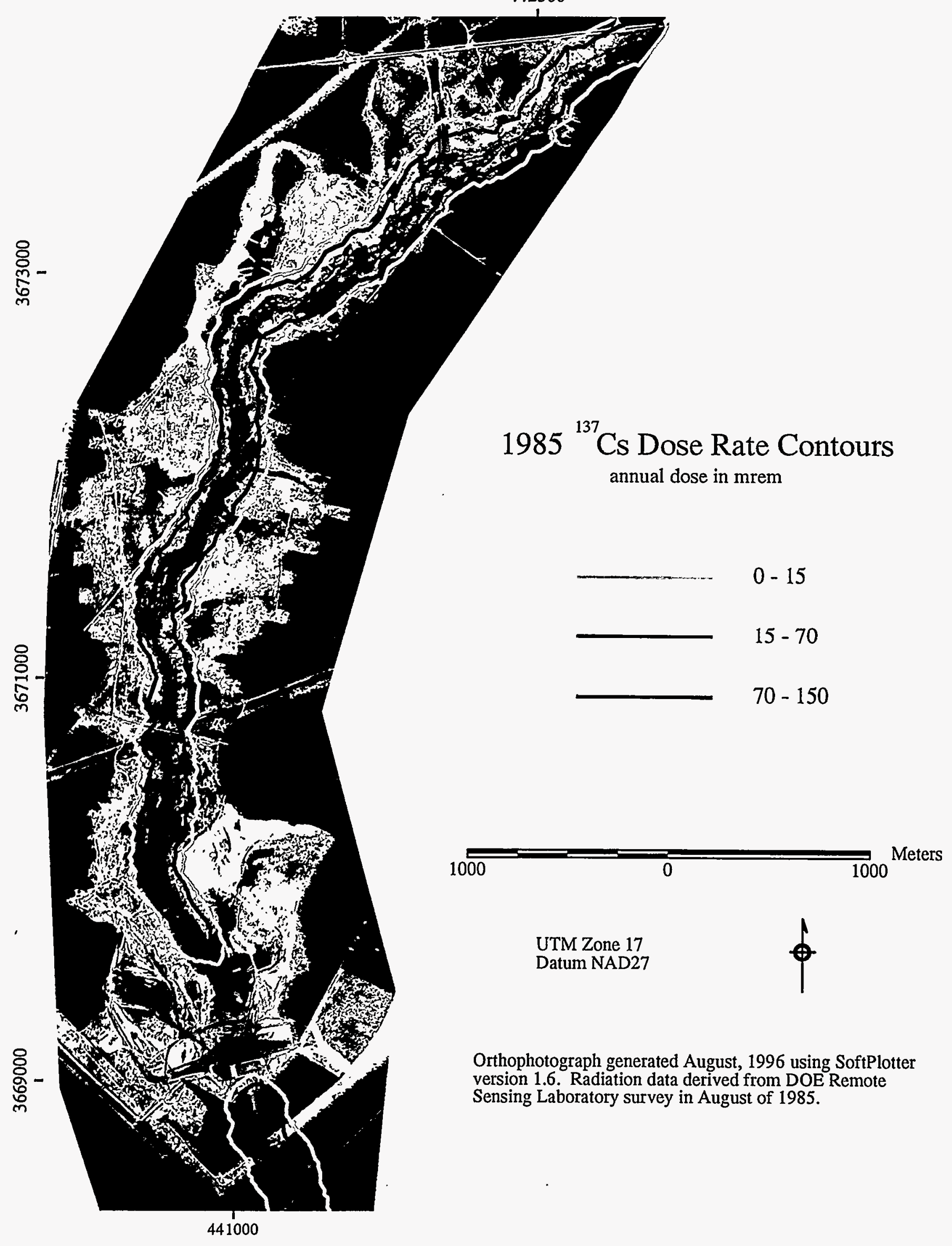

FIGURE 6. DOSE-RATE CONTOURS OF ${ }^{137}$ CS INDICATE THAT THE AREA AROUND THE DAM SITE SHOWED NO EVIDENCE OF RADIOLOGICAL ACTIVITY. 


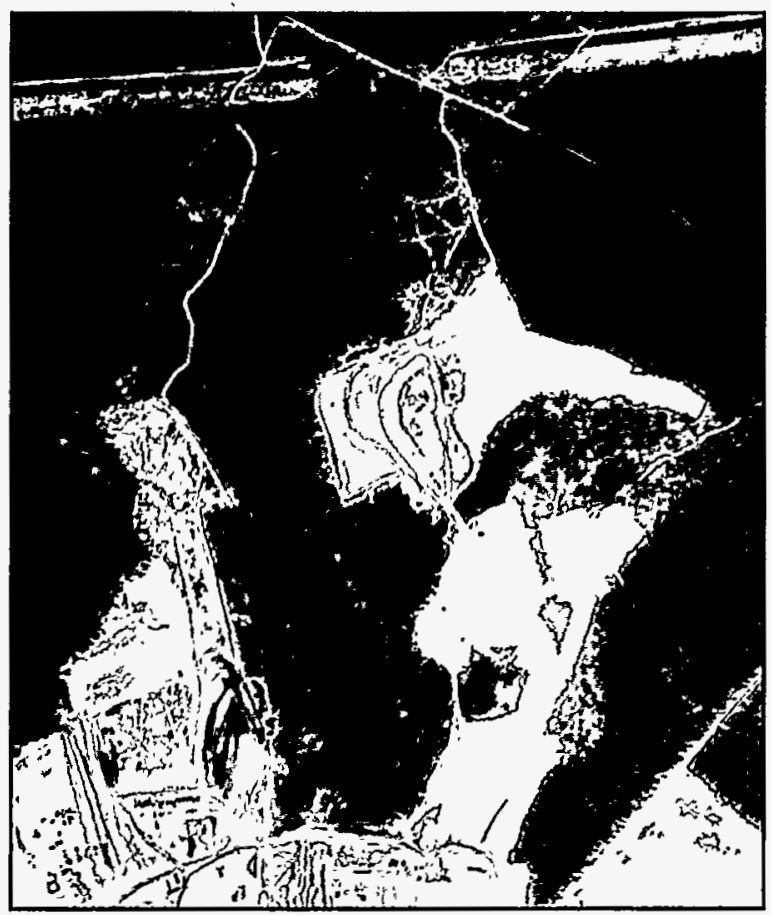

Source: EG\&G 4966-073 acquired 4-17-85 at scale 1:11900

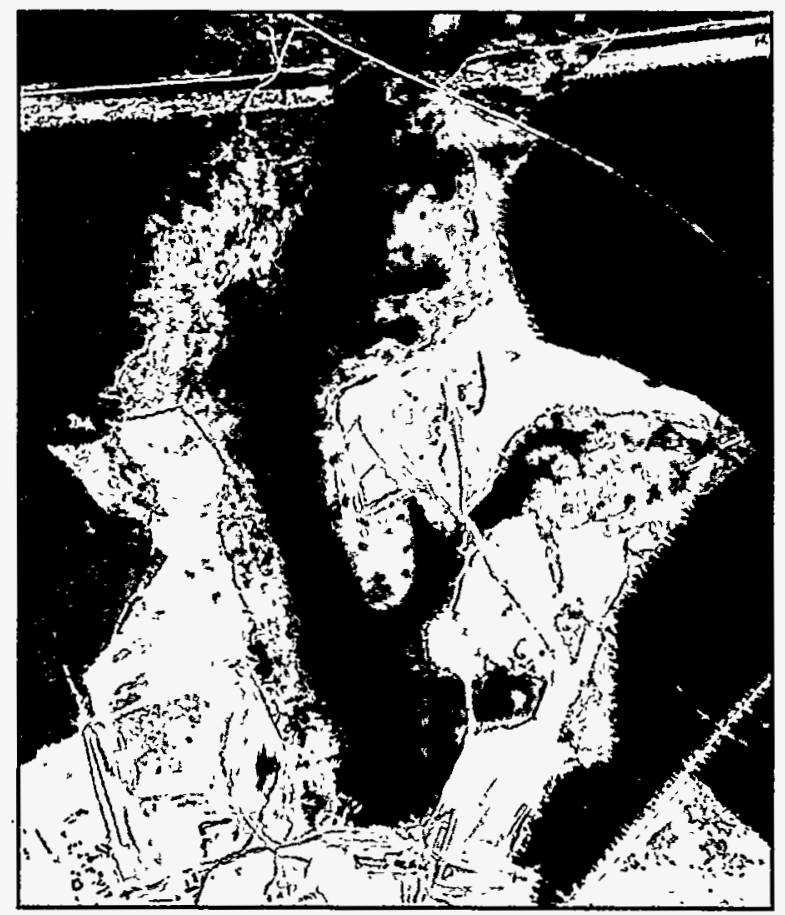

Source: EG\&G 4991-011 acquired 5-14-85 at scale 1:11900

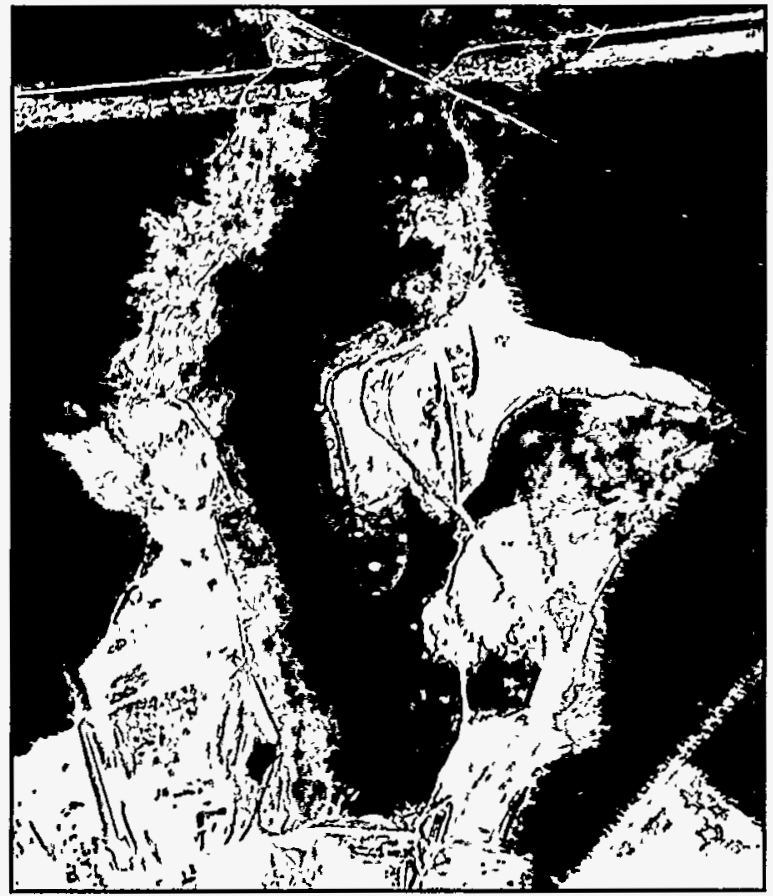

Source: EG\&G 4993-104 acquired 5-18-85 at scale 1:19900

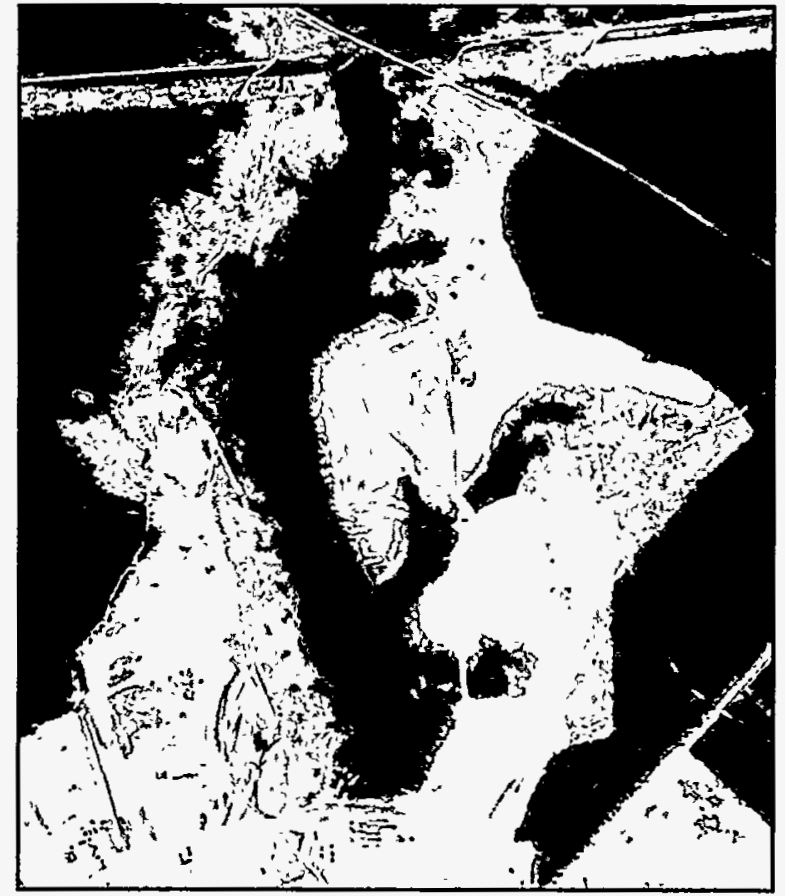

Source: EG\&G 4997-068 acquired 5-19-85 at scale 1:13900

FIGURE 7. THISPHOTOGRAPHICTIMESERIESSHOWSTHETRANSITIONFROMSTANDING VEGETATIONINTHEUPPERLEFT TO SOIL-COVERED VEGETATION ASH PILES IN THE LOWER RIGHT. 


\subsection{Softcopy Photogrammetry Orthophoto Process}

To accurately map the L Lake basin, vertical aerial photography acquired nine days before filling began was selected as the base imagery. It appears that most of the construction and clearing activities were either complete or nearly complete by this time. The timeliness and scale of the photography provided the most comprehensive visual record available for this site and, therefore, was used for the digital orthophoto mapping process described in the following sections.

\subsection{Aerial Photography Preparation}

The series of photographs used to support the digital orthophoto project for L Lake waste-unit mapping included frames 92 through 99 of EG\&G film roll 5108. The photography was acquired between 9:45 and 9:49 a.m. on September 6, 1985, with a north heading and a flying height of 7000 feet above ground level (AGL). The photographic system was a Wild Heerburg RC-10, large-format, aerial camera equipped with a 153-millimeter lens and loaded with Aerocolor 2445 film.

To accommodate the project requirement of 1-meter pixel resolution, the original spool film was scanned at 50 microns on a Howtek flatbed scanner. This resulted in pixel resolution values of approximately 0.7 meters. The binary digital photographs were converted to .img files, rotated, and reviewed using ERDAS Imagine, Version 8.2, image-processing software (ERDAS, 1995). The images were rotated so that north (the direction of the flight line) was to the right. This rotation gives the best parallax for the correlation function employed during the orthorectification process. Based predominantly on overlap and scan quality, frames $92,94,96,97,98$, and 99 were selected and imported into SoftPlotter $^{\top M}$ Version 1.6, Vision International's softcopy orthophotogrammetric package (Vision International, Inc., 1996).

For best results from SoftPlotter, camera calibration information is required. Each camera and lens setup used in aerial acquisitions by the DOE RSL is sent at regular intervals to the manufacturer or the U.S. Geological Survey (USGS) for inspection, cleaning, and calibration. Lens calibration information for the camera configuration used for the L Lake photography was obtained from Leica NA, Inc. The camera calibration certificate lists important lens information including the calibrated focal length, the principal point of symmetry, and the radial distortion away from the principal point of symmetry. The manufacturer's fiducial mark locations with respect to the focal center of the camera frame are also given. All of these values are used by the SoftPlotter Interior Orientation routine to calculate the mathematical relationships between the camera and the lens and the lens and the ground.

\subsection{Project Definition and Processing}

In SoftPlotter, the "L Lake Project" was defined, the camera type and values were entered, and the six selected Imagine .img formatted images were imported. Interior orientation was performed and each image was reviewed. During this process, the operator has the opportunity to hand edit the fiducial locations by interactively selecting the best center for each fiducial. This iterative process tells the operator where problem areas may exist on each image due to poor scan quality, film damage, or mismeasurement. The user defines the maximum acceptable root mean square error (RMSE) for the solution and can modify the location and number of fiducials used to perform the interior orientation until the requirements are met. For this project, the allowable RMSE was kept to the equivalent of 1 meter or 1.4 pixels. 
Once information pertaining to the camera-lens relationship has been determined, ground control points (gcps) are defined in order to calculate the photograph/ground relationship. Gcps for this project came from a variety of sources. Table 2 shows the type and source of each of the gcps used for the triangulation portion of the block adjustment.

Results of the triangulation process are dependant on several user defined constraints. These parameters are selected based on knowledge of the factors affecting photographic acquisition and film quality. Rigid constraints can be employed when optimum conditions such as the following are met: known flying height, good film quality, minor distortions in photography due to flight parameters, gentle topography, and adequate ground control. Optimum conditions were met for the $L$ Lake project, so rigid constraints were used. Based upon image RMSE residuals for $\mathrm{x}, \mathrm{y}$, and $\mathrm{z}$ values, the triangulation process yielded acceptable results.

\subsection{Stereopair Generation}

Epipolar resampling of the triangulated overlapping imagery was performed using the proprietary algorithms provided in the Stereo Tool module in SoftPlotter. This process resulted in five stereopairs of images that were oriented such that $y$-parallax was removed and $x$-parallax was interpreted as differences in elevation. The stereopairs were displayed to quality check the apparent success of the resampling before the DEM was generated.

\subsection{DEM Generation}

The five stereopairs were used as the sources for the DEM. Collection parameters were defined with a ground spacing of 1 meter, and a DEM was produced for each stereopair. This was an iterative process and the most time-intensive because the software provides ample methods for improving posting results through the use of breaklines and other site-specific point and surface adjustments. For L Lake, the forest edge was the biggest consideration during the editing process. Special attention was given to those areas directly affecting the shoreline elevations.

When the DEMs for each stereopair were deemed acceptable, they were mosaicked using Imagine's Mosaic routine. The result of this process is shown in Figure 8. Based on known and map-measured check points, elevation errors of the DEM ranged from $0.037-1.700$ meters. Horizontal accuracies were less than 10 meters.

Table 2. Control Point Information

\begin{tabular}{l|c|l}
\hline Type & Number & Source \\
\hline Horizontal & 13 & Differential GPS $^{a}$ \\
Vertical & 7 & USGS Quadrangles $^{b}$ \\
Tie Points & 6 & Frame Feature $^{-}$ \\
\hline
\end{tabular}

a Global Positioning System provided by R.S. Riley and

H. Mackey, Westinghouse Savannah River Company.

b Girard NW and Girard NE 7.5-minute series (USGS, 1964). 


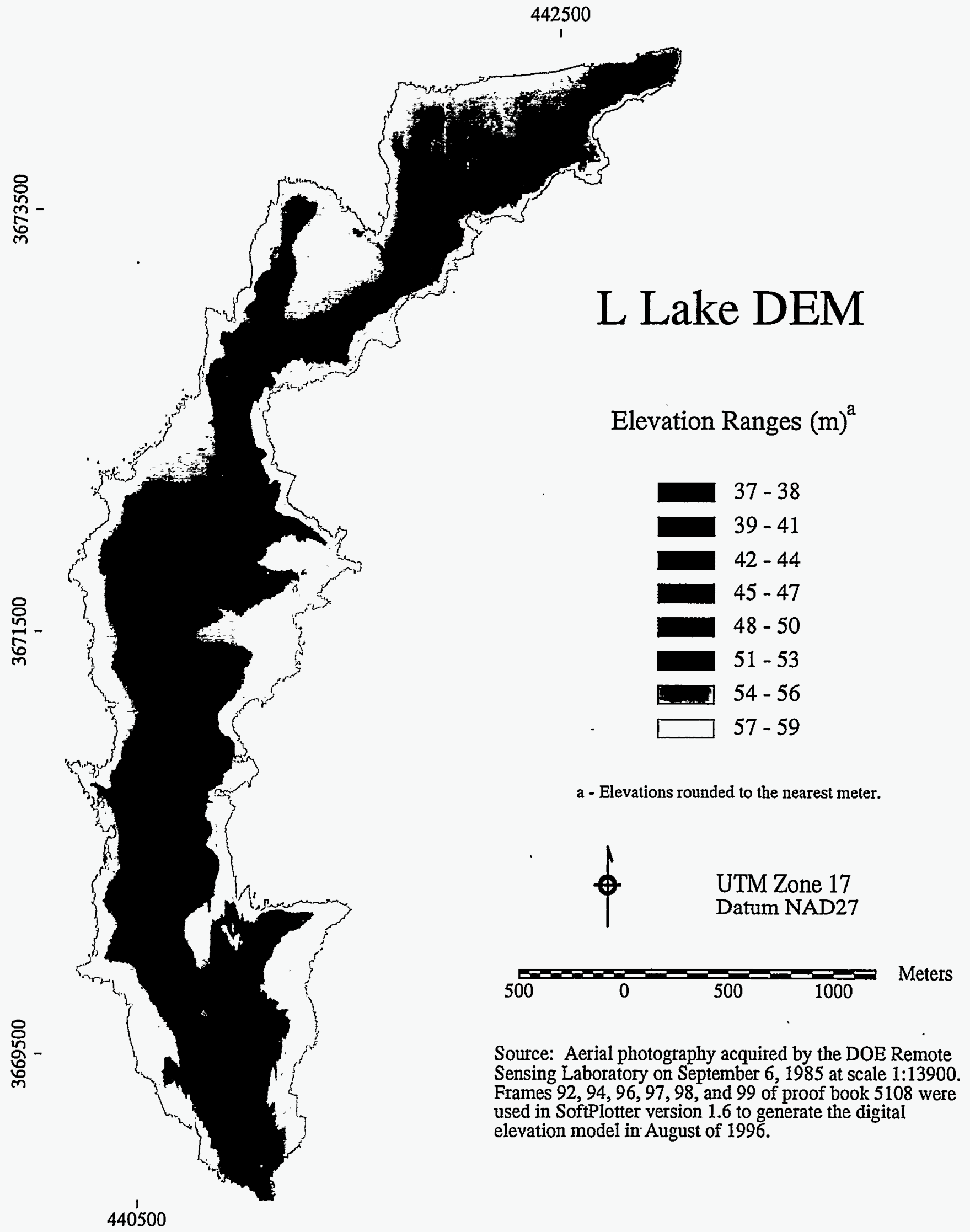

FIGURE 8. LEVEL-SLICED DEM SHOWING ELEVATION RANGES 


\subsection{Digital Orthophoto Generation}

Orthophotographs were derived from the six images and the DEM using a defined ground spacing of 1 meter in the Ortho Tool module in SoftPlotter. As with the DEMs, the orthophotos were merged using Imagine's Mosaic routine. The resulting orthorectified image is shown in Figure 9. This image and the DEM were subsequently used to generate raster products (ERDAS, 1995) and ARC/INFO vector coverages (ESRI, 1996) to help determine the location, extent, and type of disturbances that were visible in the lake bed on September 6, 1985, just prior to the initial fill date nine days later.

\subsection{Digital Orthophotointerpretation Results}

The seven categories of map features shown in Figure 10 were derived during the preliminary review of the source photography. A larger-scale map is also provided in Appendix C. Area statistical results of the digital orthophotointerpretation for these categories are listed in Table 3. In Figure 10, the large waste units shown in pink are evident, but there remains some confusion as to the absolute extent of where waste is actually buried and where soil was merely disturbed during the containment effort. The temporal sequence of both aerial and ground photography indicates that these were the primary areas used for the removal, transport, dumping, covering, and subsequent containment of the majority of the dam site materials believed to be contaminated. The dam site was constructed using imported materials in conjunction with the materials extracted from the borrow pits. The area occupied by the two waste units is just under 6 hectares.

The potential waste units, indicated in dark blue in Figure 10, depict those areas where it appears that other materials, perhaps those not suitable for construction purposes due to physical properties, have been deposited for containment. These 11 areas covered just over 19 hectares of the lake bed.

The vegetation waste piles, shown in red in Figure 10, are thought to contain contaminated vegetation not suitable for removal or burning. The photography indicates that the vegetation was bulldozed into piles and covered with soil for containment. A total of 154 of these areas occupies approximately 6.4 hectares of the lake bed closest to the floodplain. Some of the piles are actually in the floodplain.

Table 3. Area Statistics

\begin{tabular}{l|c|c|c}
\hline Cover Type & Occurrences & $\begin{array}{c}\text { Mean } \\
\text { Size } \\
\text { (ha) }\end{array}$ & Sum \\
\hline Large Waste Units & 2 & 2.94 & 5.87 \\
Vegetation Waste Piles & 154 & 0.04 & 6.42 \\
Ash Piles & 584 & 0.04 & 21.41 \\
Potential Waste Units & 11 & 1.74 & 19.17 \\
Debris Piles & 13 & 0.04 & 0.46 \\
Borrow Pits & 4 & 2.47 & 9.87 \\
Fish Structures & 27 & 0.01 & 0.21 \\
\hline \multicolumn{3}{|c}{ Total } & 63.41 \\
\hline
\end{tabular}




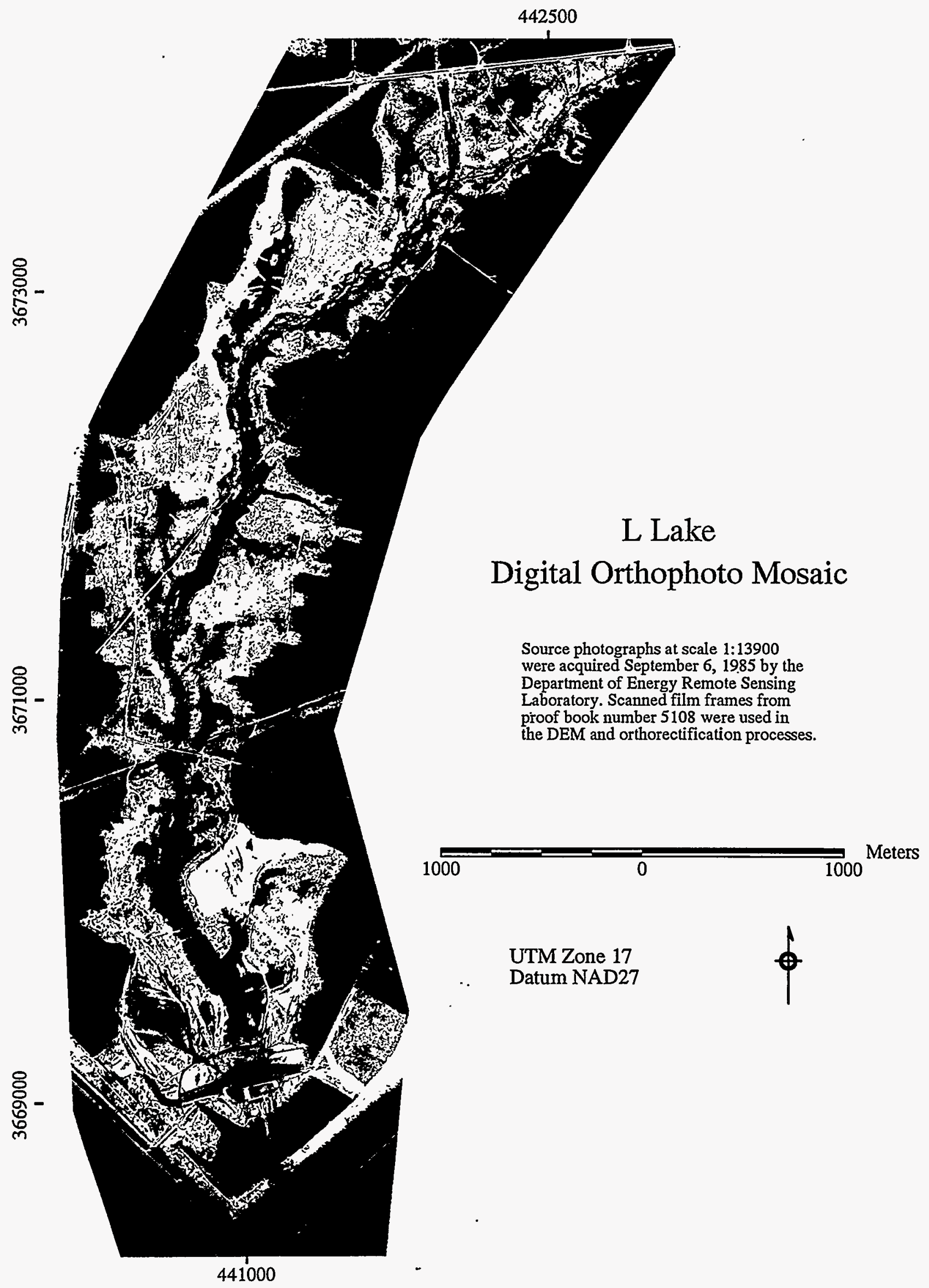

FIGURE 9. MOSAICKED DIGITAL ORTHOPHOTOGRAPH OF THE L LAKE BASIN DERIVED FROM FIVE SEPARATE PHOTOGRAPHS. 


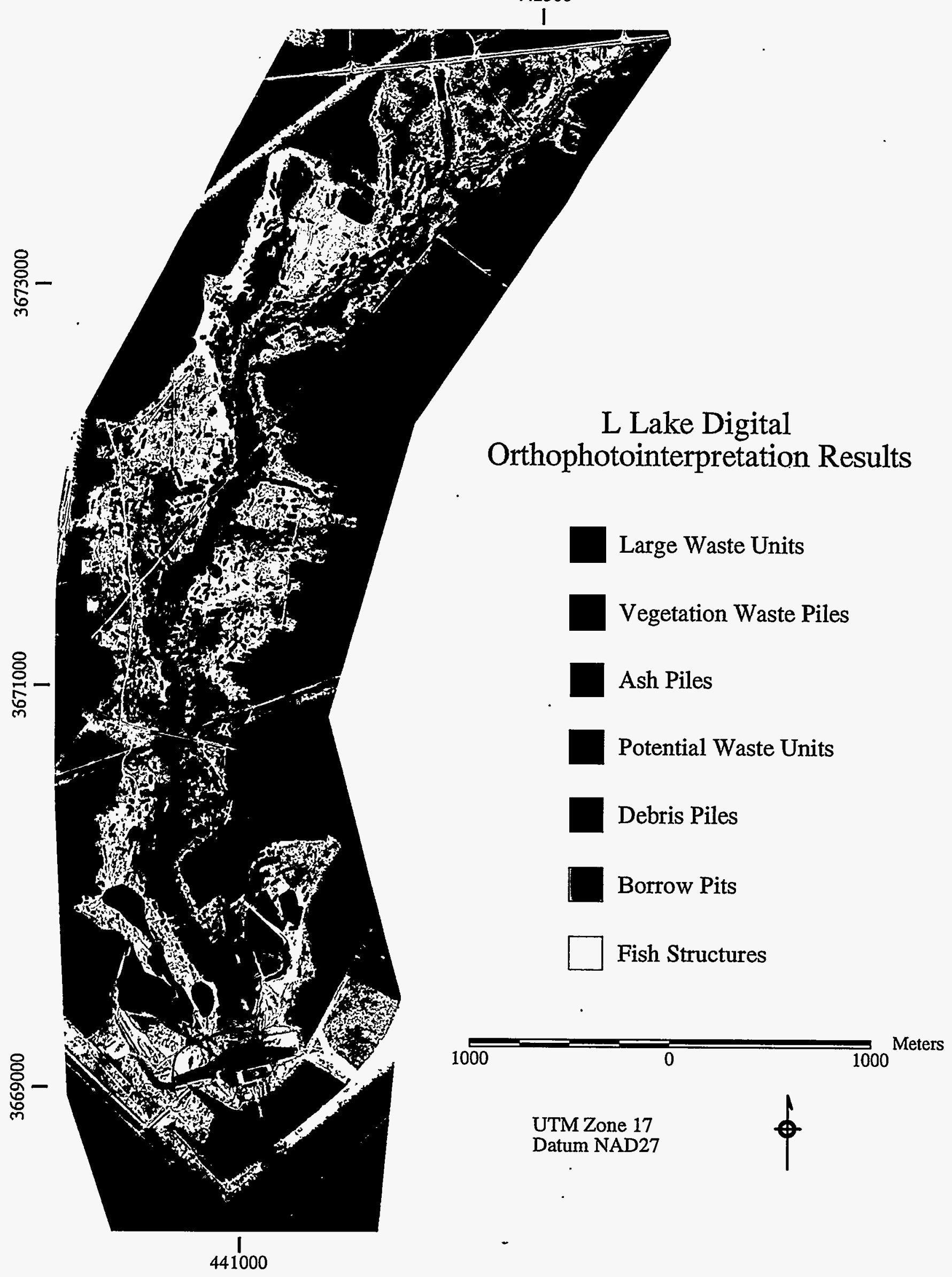

FIGURE 10. SEVEN TYPES OF FEATURES OF INTEREST WERE INTERPRETED FROM THE DIGITAL ORTHOPHOTOGRAPH. 
The locations of these piles are thought to be the result of the intent to keep them within reasonable distance of the "contamination line" shown in blue in Figure 11. The contamination line was determined by deriving acceptable levels of terrestrial radioactivity based on ground-based dosimeter measurements. The line data shown in Figure 11 were derived from the topographic map series designed in April 1984 by Baldwin and Cranston Associates, Inc., entitled Cooling Reservoir Site, "L"Area, Savannah River Plant. The four-map series was revised in September 1984 to include the contamination line.

The 584 ash piles, denoted in green in Figure 10 , account for 21.41 hectares of the lake bed area. These features are the result of the vegetation-clearing effort where bulldozers were used to scrape the vegetation into piles. The piles were then burned, and the remaining ashes were covered with clean soil. The soil used to cover the ashes may have come from one of the four borrow pits shown in cyan in Figure 10 or, more than likely, was scraped from a cleared area nearby. Almost 10 hectares of the area cleared for L Lake was used for borrow pit materials.

To facilitate the establishment of fish and macrophyte populations in L Lake, approximately 40 concrete block and vegetation piles, including the trunks of trees deemed unsuitable for sale, were positioned throughout the lake bed as initial habitats. These fish structures and debris piles are shown as orange and purple polygons, respectively, in Figure 10.

As mentioned previously, soil-suitability tests were performed in areas in close proximity to the dam construction site. The locations of soils that had the correct physical properties for construction or for use in covering the waste and debris piles are denoted as cyan polygons and cover an area of approximately 9.9 hectares. The northernmost borrow pit existed prior to L Lake construction, but the photography suggests that it was also modified during $L$ Lake development.

\subsection{Summary}

Based on the digital orthophotography, the aerial extent of disturbances within the $L$ Lake basin is approximately 63.4 hectares. The seven categories of disturbances have been mapped and prioritized in the legend according to their likelihood of containing low-level radioactive materials. By using the digital maps in conjunction with the DEM, scientists can now use the information available in the L Lake GIS to reasonably model and estimate the extent to which these features will be exposed in the event that the lake is drawn down. The centroid locations and elevations for each feature type occurrence, which is identified with its ARC/INFO - id value, are listed in Appendix D. 


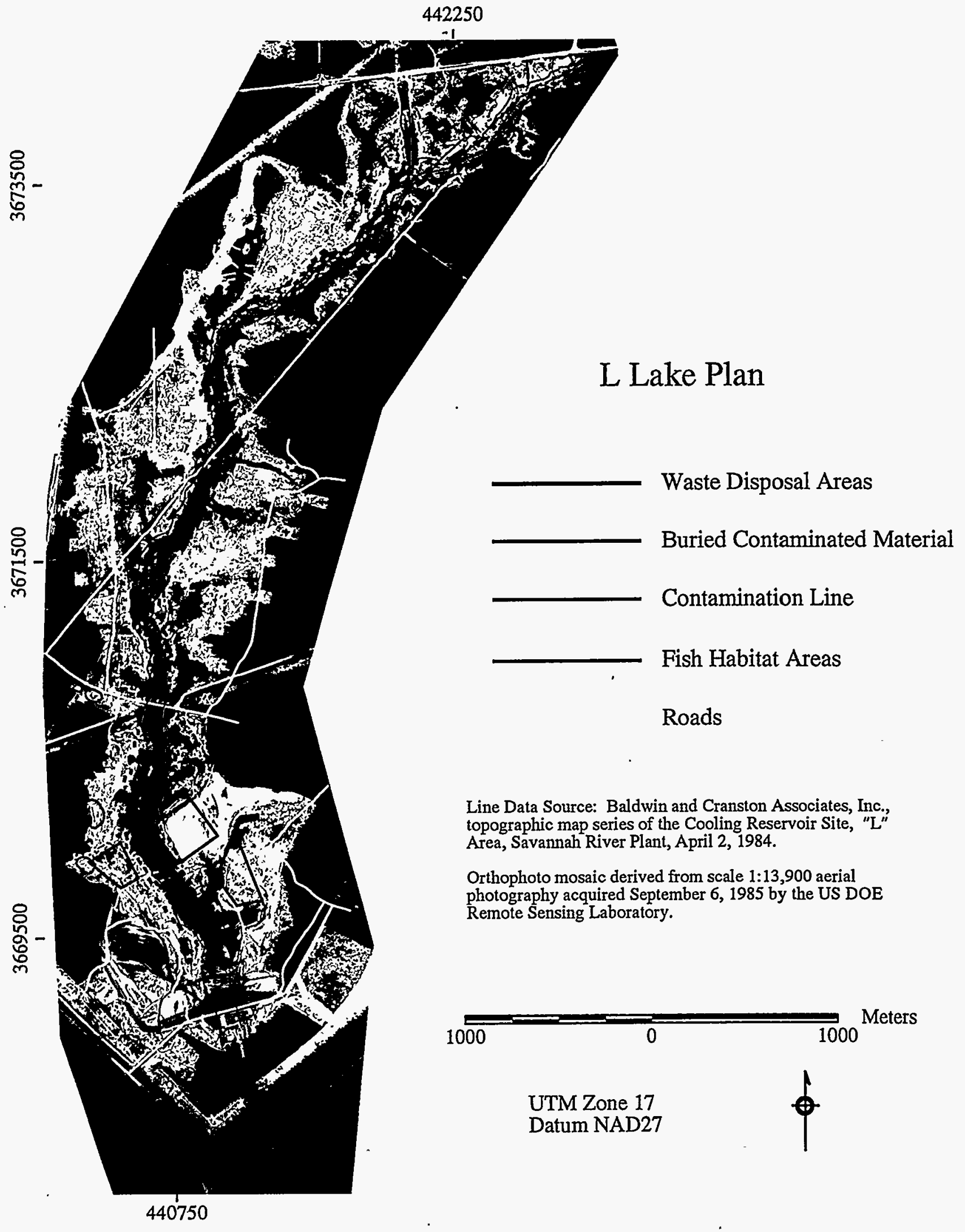

FIGURE 11. VECTOR LAYERS DIGITIZED FROM ENGINEERING PLANS OVERLAYED ON THE DIGITAL ORTHOPHOTOGRAPH. 


\section{APPENDIX A}

\section{VERTICAL AERIAL PHOTOGRAPHY USED FOR PHOTOINTERPRETATION AND MAPPING}

Table A-1 is a comprehensive list of the vertical aerial photography used for the photointerpretation and mapping processes for the $L$ Lake project. Altitudes are given as above ground level in feet.

Table A-1. Vertical Aerial Photography

\begin{tabular}{l|l|l|c|l|l}
\hline Proof No. & Frames & Date & $\begin{array}{c}\text { Altitude } \\
\text { (ft) }\end{array}$ & Scale & Film Type \\
\hline EG\&G 4655 & 006 & $03 / 31 / 84$ & 17000 & $1: 34400$ & color \\
EG\&G 4644 & 006 & $03 / 31 / 84$ & 17000 & $1: 34400$ & color infrared \\
EG\&G 4655 & $161-164$ & $04 / 01 / 84$ & 8000 & $1: 15700$ & color \\
EG\&G 4755 & 174,194 & $06 / 18 / 84$ & 10000 & $1: 19900$ & color \\
EG\&G 4840 & $16-22$ & $09 / 19 / 84$ & 20000 & $1: 39200$ & color \\
& $63-86$ & & 8000 & $1: 7960$ & color \\
EG\&G 4966 & $062-063$ & $04 / 17 / 85$ & 20000 & $1: 41400$ & color \\
& 073 & & 6000 & $1: 11900$ & color \\
EG\&G 4973 & $105-112$ & $04 / 25 / 85$ & 4000 & $1: 7960$ & color \\
EG\&G 4991 & $010-019$ & $05 / 14 / 85$ & 6000 & $1: 11900$ & color \\
EG\&G 4992 & $010-019$ & $05 / 14 / 85$ & 6000 & $1: 11900$ & color infrared \\
EG\&G 4993 & $084-104$ & $05 / 18 / 85$ & 10000 & $1: 19900$ & color \\
EG\&G 4994 & $084-104$ & $05 / 18 / 85$ & 10000 & $1: 19900$ & color infrared \\
EG\&G 4997 & $066-073$ & $05 / 19 / 85$ & 7000 & $1: 13900$ & color \\
EG\&G 4998 & $066-073$ & $05 / 19 / 85$ & 7000 & $1: 13900$ & color infrared \\
EG\&G 5033 & $075-081$ & $06 / 21 / 85$ & 6000 & $1: 11900$ & color \\
& 082 & & 17000 & $1: 33800$ & color \\
EG\&G 5108 & 088 & $09 / 06 / 85$ & 20000 & $1: 39200$ & color \\
& $092-100$ & & 7000 & $1: 13900$ & color \\
\hline
\end{tabular}




\section{APPENDIX B \\ DOE RADIOLOGICAL SURVEY DOCUMENTS}

Information regarding aerial gamma radiological surveys of the Steel Creek area before the L Lake fill date can be found in the following DOE reports:

Jobst, J.E. An Aerial Radiological Survey of the Savannah River Plant Drainage Basins, Date of Survey: August 1982. DOE/ONS-8312, Rev. 1, EG\&G/EM, Las Vegas, Nevada, 1987.

Jobst, J.E. An Aerial Radiological Survey of the L Lake and Steel Creek, Savannah River Plant, Survey Date: August 1985. DOE(ONS-SRL)-8611, EG\&G/EM, Las Vegas, Nevada, 1988.

Information regarding aerial gamma radiological surveys of the Steel Creek area after the $L$ Lake fill date can be found in the following DOE reports:

Feimster, E.L. An Aerial Radiological Survey of the L Lake and Steel Creek, Savannah River Site, Date of Survey: July 1986. EGG-10617-1146, EG\&G/EM, Las Vegas, Nevada, 1992.

Feimster, E.L. An Aerial Radiological Survey of Par Pond and Associated Drainage Pathways of the Savannah River Site, Aiken, South Carolina, Date of Survey: August 19-November 11, 1991. EGG-10617-1227, EG\&G/EM, Las Vegas, Nevada, 1992.

Vojtech, R.J. An Aerial Radiological Survey of the Savannah River Site and Surrounding Area October-November 1991, Aiken, South Carolina. EGG-11265-1236, EG\&G/EM, Las Vegas, Nevada, 1993. 


\section{APPENDIX C ENLARGED MOSAIC}




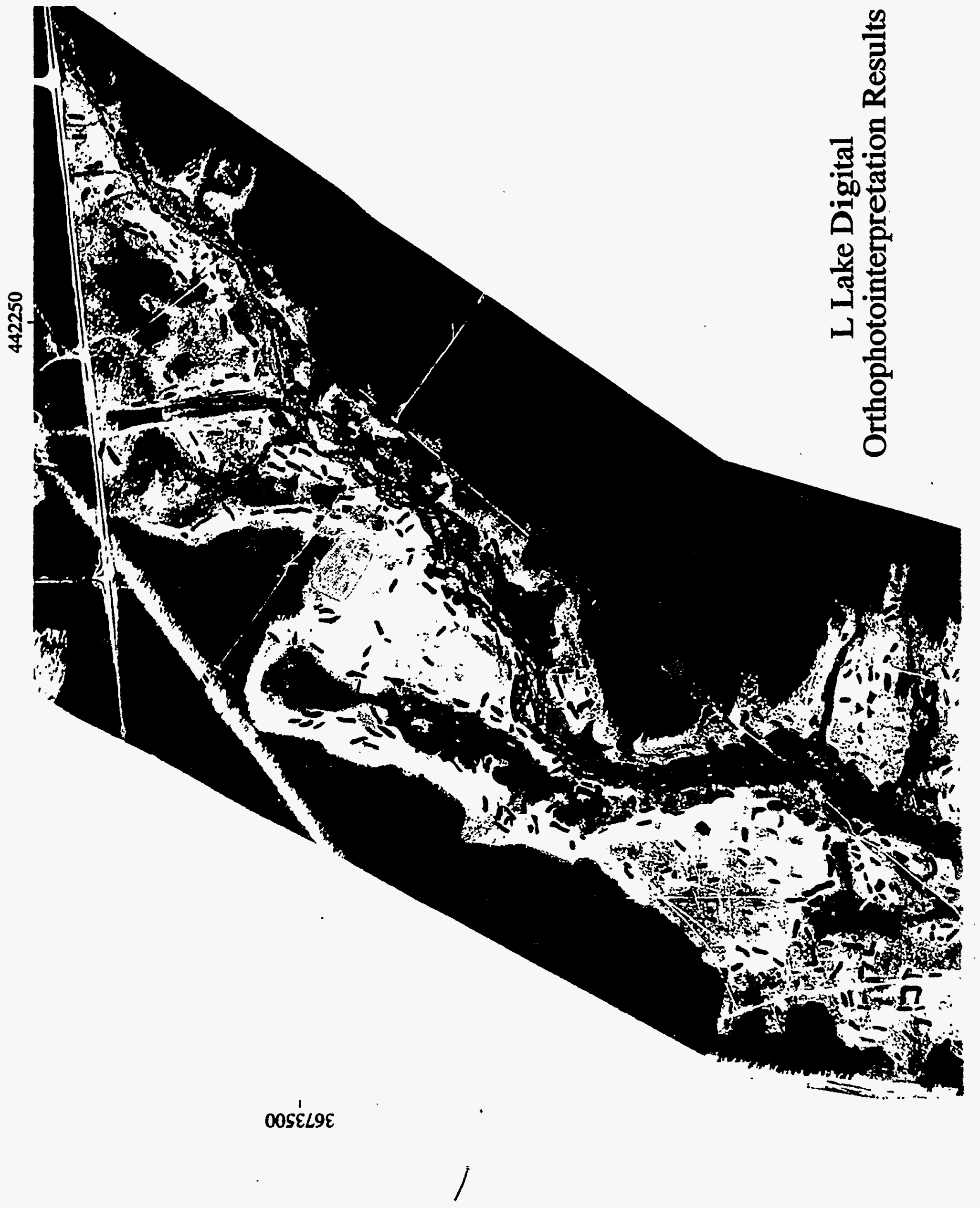




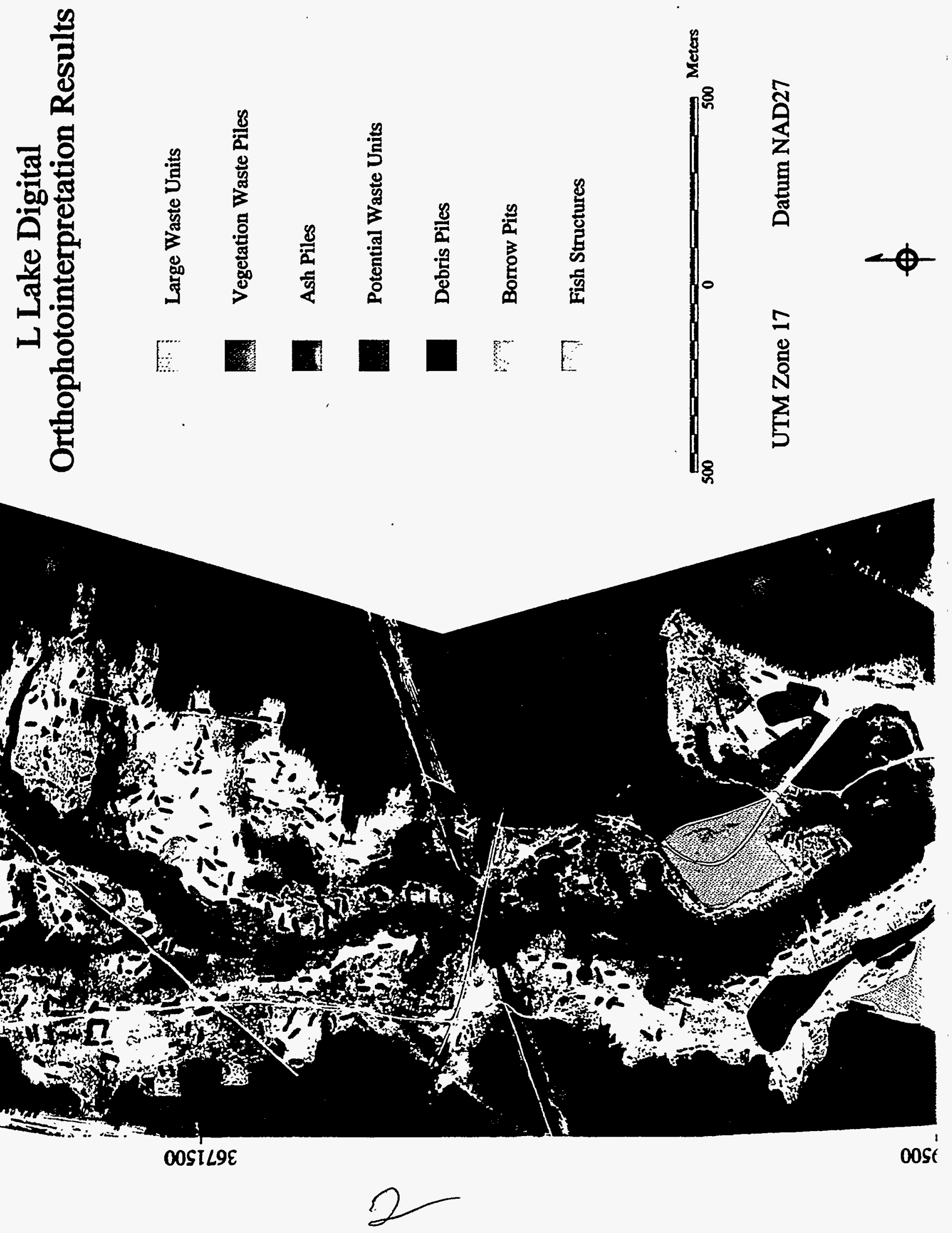




\section{APPENDIX D \\ LOCATIONS AND ELEVATIONS OF PHOTOINTERPRETATED MAP FEATURES}

The following tabular data are the listing of locations and elevations for the seven informations classes derived from the digital orthophotograph and DEM. The ID No. values correspond to the ARC/INFO coverage -id attribute. Information is given in meters above mean sea level.

Table D-1. Locations and Elevations of Large Waste Units

\begin{tabular}{c|c|c|c}
\hline $\begin{array}{c}\text { Unit } \\
\text { ID No. }\end{array}$ & $\begin{array}{c}\text { Easting } \\
\text { UTM }^{\mathrm{a}}\end{array}$ & $\begin{array}{c}\text { Northing } \\
\text { UTM }\end{array}$ & $\begin{array}{c}\text { Elevation } \\
\text { NAD27 }\end{array}$ \\
\hline 9 & $440,785.3$ & $3,670,040.3$ & 55.7 \\
31 & $440,888.5$ & $3,670,101.7$ & 50.2 \\
\hline
\end{tabular}

a Universal Transverse Mercator

Table D-2. Location and Elevations of Vegetation Waste Units

\begin{tabular}{c|c|c|c}
\hline $\begin{array}{c}\text { Unit } \\
\text { ID No. }\end{array}$ & $\begin{array}{c}\text { Easting } \\
\text { UTM }\end{array}$ & $\begin{array}{c}\text { Northing } \\
\text { UTM }\end{array}$ & $\begin{array}{c}\text { Elevation } \\
\text { NAD27 }\end{array}$ \\
\hline 2 & $442,824.0$ & $3,674,052.9$ & 50.5 \\
3 & $442,773.7$ & $3,674,029.9$ & 51.3 \\
4 & $442,713.4$ & $3,673,962.9$ & 53.7 \\
5 & $442,679.9$ & $3,673,946.5$ & 53.6 \\
6 & $442,657.4$ & $3,673,938.4$ & 52.5 \\
7 & $442,650.1$ & $3,673,922.7$ & 53.9 \\
8 & $442,559.4$ & $3,673,906.2$ & 52.0 \\
9 & $442,608.9$ & $3,673,893.6$ & 52.2 \\
10 & $442,539.6$ & $3,673,877.2$ & 51.1 \\
11 & $442,601.8$ & $3,673,857.8$ & 51.3 \\
12 & $442,516.0$ & $3,673,851.9$ & 51.4 \\
13 & $442,585.8$ & $3,673,827.5$ & 53.1 \\
14 & $442,465.3$ & $3,673,791.2$ & 50.9 \\
15 & $442,624.4$ & $3,673,766.2$ & 54.7 \\
16 & $442,429.6$ & $3,673,769.0$ & 52.4 \\
17 & $442,026.1$ & $3,673,761.9$ & 51.6 \\
18 & $442,559.7$ & $3,673,760.8$ & 51.8 \\
19 & $442,458.2$ & $3,673,757.0$ & 51.7 \\
\hline
\end{tabular}


Table D-2. Location and Elevations of Vegetation Waste Units (continued)

\begin{tabular}{|c|c|c|c|}
\hline $\begin{array}{l}\text { Unit } \\
\text { ID No. }\end{array}$ & $\begin{array}{c}\text { Easting } \\
\text { UTM }\end{array}$ & $\begin{array}{c}\text { Northing } \\
\text { UTM }\end{array}$ & $\begin{array}{c}\text { Elevation } \\
\text { NAD27 }\end{array}$ \\
\hline 20 & $442,553.0$ & $3,673,746.5$ & 51.1 \\
\hline 21 & $442,375.9$ & $3,673,745.1$ & 52.7 \\
\hline 22 & $442,541.3$ & $3,673,737.0$ & 51.6 \\
\hline 23 & $441,993.3$ & $3,673,728.2$ & 52.1 \\
\hline 24 & $442,394.1$ & $3,673,731.7$ & 51.4 \\
\hline 25 & $442,364.7$ & $3,673,717.9$ & 52.6 \\
\hline 26 & $442,478.5$ & $3,673,698.5$ & 52.6 \\
\hline 27 & $442,276.3$ & $3,673,675.5$ & 51.7 \\
\hline 28 & $442,227.2$ & $3,673,652.7$ & 52.5 \\
\hline 29 & $442,439.5$ & $3,673,669.8$ & 52.0 \\
\hline 30 & $442,116.1$ & $3,673,619.8$ & 51.4 \\
\hline 31 & $441,972.5$ & $3,673,610.5$ & 53.1 \\
\hline 32 & $442,377.4$ & $3,673,597.8$ & 52.5 \\
\hline 33 & $442,101.0$ & $3,673,596.5$ & 50.8 \\
\hline 34 & $441,901.7$ & $3,673,595.2$ & 51.9 \\
\hline 35 & $441,969.2$ & $3,673,577.0$ & 52.7 \\
\hline 36 & $442,098.3$ & $3,673,525.4$ & 50.5 \\
\hline 37 & $442,061.3$ & $3,673,499.4$ & 52.3 \\
\hline 38 & $442,142.2$ & $3,673,480.5$ & 52.8 \\
\hline 39 & $441,979.2$ & $3,673,407.5$ & 50.6 \\
\hline 40 & $441,944.8$ & $3,673,358.4$ & 51.2 \\
\hline 41 & $441,808.6$ & $3,673,333.1$ & 52.5 \\
\hline 42 & $441,920.5$ & $3,673,272.6$ & 52.1 \\
\hline 43 & $441,672.5$ & $3,673,142.7$ & 50.9 \\
\hline 44 & $441,547.0$ & $3,673,139.8$ & 55.4 \\
\hline 45 & $441,595.1$ & $3,673,127.6$ & 53.4 \\
\hline 46 & $441,791.0$ & $3,673,110.8$ & 52.8 \\
\hline 47 & $441,735.0$ & $3,673,105.2$ & 51.3 \\
\hline 48 & $441,496.8$ & $3,673,092.8$ & 54.0 \\
\hline 49 & $441,473.0$ & $3,673,061.4$ & 52.0 \\
\hline 50 & $441,697.7$ & $3,673,052.8$ & 51.6 \\
\hline 51 & $441,400.3$ & $3,672,969.6$ & 51.0 \\
\hline 52 & $441,511.3$ & $3,672,897.9$ & 53.8 \\
\hline
\end{tabular}


Table D-2. Location and Elevations of Vegetation Waste Units (continued)

\begin{tabular}{|c|c|c|c|}
\hline $\begin{array}{l}\text { Unit } \\
\text { ID No. }\end{array}$ & $\begin{array}{c}\text { Easting } \\
\text { UTM }\end{array}$ & $\begin{array}{c}\text { Northing } \\
\text { UTM }\end{array}$ & $\begin{array}{c}\text { Elevation } \\
\text { NAD27 }\end{array}$ \\
\hline 53 & $441,203.4$ & $3,672,900.8$ & 52.0 \\
\hline 54 & $441,304.2$ & $3,672,890.8$ & 51.8 \\
\hline 55 & $441,092.4$ & $3,672,838.8$ & 50.8 \\
\hline 56 & $441,059.9$ & $3,672,805.2$ & 50.1 \\
\hline 57 & $441,316.3$ & $3,672,798.9$ & 51.2 \\
\hline 58 & $441,189.8$ & $3,672,794.1$ & 51.7 \\
\hline 59 & $441,390.5$ & $3,672,792.3$ & 51.6 \\
\hline 60 & $441,031.8$ & $3,672,780.3$ & 49.8 \\
\hline 61 & $441,146.6$ & $3,672,761.1$ & 51.1 \\
\hline 62 & $441,005.5$ & $3,672,762.2$ & 49.0 \\
\hline 63 & $440,945.8$ & $3,672,702.0$ & 50.5 \\
\hline 64 & $440,914.9$ & $3,669,304.5$ & 44.5 \\
\hline 65 & $440,963.9$ & $3,672,695.5$ & 49.8 \\
\hline 66 & $441,012.4$ & $3,672,501.7$ & 51.6 \\
\hline 67 & $441,029.7$ & $3,672,408.5$ & 51.6 \\
\hline 68 & $440,934.4$ & $3,672,318.6$ & 48.3 \\
\hline 69 & $441,068.5$ & $3,672,290.5$ & 51.7 \\
\hline 70 & $440,963.7$ & $3,672,269.4$ & 47.6 \\
\hline 71 & $441,087.3$ & $3,672,237.4$ & 50.5 \\
\hline 72 & $441,102.6$ & $3,672,174.5$ & 50.3 \\
\hline 73 & $441,111.6$ & $3,672,110.2$ & 47.0 \\
\hline 74 & $441,097.6$ & $3,672,058.9$ & 47.0 \\
\hline 75 & $440,942.6$ & $3,672,016.5$ & 45.0 \\
\hline 76 & $441,059.5$ & $3,672,003.7$ & 45.5 \\
\hline 77 & $441,014.2$ & $3,671,953.7$ & 46.7 \\
\hline 78 & $440,970.2$ & $3,671,905.1$ & 46.7 \\
\hline 79 & $440,840.4$ & $3,671,882.2$ & 45.0 \\
\hline 80 & $440,957.0$ & $3,671,854.5$ & 49.2 \\
\hline 81 & $440,749.0$ & $3,671,759.9$ & 46.8 \\
\hline 82 & $440,973.6$ & $3,671,736.4$ & 49.6 \\
\hline 83 & $440,883.0$ & $3,671,704.4$ & 47.6 \\
\hline 84 & $440,717.1$ & $3,671,649.0$ & 46.5 \\
\hline 85 & $440,841.0$ & $3,671,631.7$ & 47.4 \\
\hline
\end{tabular}


Table D-2. Location and Elevations of Vegetation Waste Units (continued)

\begin{tabular}{|c|c|c|c|}
\hline $\begin{array}{l}\text { Unit } \\
\text { ID No. }\end{array}$ & $\begin{array}{c}\text { Easting } \\
\text { UTM }\end{array}$ & $\begin{array}{l}\text { Northing } \\
\text { UTM }\end{array}$ & $\begin{array}{c}\text { Elevation } \\
\text { NAD27 }\end{array}$ \\
\hline 86 & $440,797.5$ & $3,671,564.0$ & 46.7 \\
\hline 87 & $440,600.1$ & $3,671,547.9$ & 45.3 \\
\hline 88 & $440,743.9$ & $3,671,519.5$ & 47.8 \\
\hline 89 & $440,719.9$ & $3,671,487.2$ & 47.9 \\
\hline 90 & $440,580.9$ & $3,671,469.8$ & 44.3 \\
\hline 91 & $440,711.8$ & $3,671,449.7$ & 49.5 \\
\hline 92 & $440,576.9$ & $3,671,453.4$ & 44.6 \\
\hline 93 & $440,717.9$ & $3,671,406.1$ & 48.0 \\
\hline 94 & $440,504.5$ & $3,671,326.2$ & 46.8 \\
\hline 95 & $440,690.0$ & $3,671,319.9$ & 44.8 \\
\hline 96 & $440,508.8$ & $3,671,279.5$ & 46.8 \\
\hline 97 & $440,653.2$ & $3,671,281.1$ & 44.6 \\
\hline 98 & $440,647.7$ & $3,671,243.3$ & 45.1 \\
\hline 99 & $440,505.3$ & $3,671,217.5$ & 46.7 \\
\hline 100 & $440,546.1$ & $3,671,171.1$ & 44.1 \\
\hline 101 & $440,648.7$ & $3,671,184.9$ & 44.4 \\
\hline 102 & $440,658.5$ & $3,671,162.3$ & 45.1 \\
\hline 103 & $440,569.0$ & $3,671,139.9$ & 43.2 \\
\hline 104 & $440,704.2$ & $3,671,132.1$ & 44.5 \\
\hline 105 & $440,601.4$ & $3,671,075.3$ & 44.8 \\
\hline 106 & $440,726.3$ & $3,671,051.2$ & 43.2 \\
\hline 107 & $440,746.4$ & $3,671,038.4$ & 44.0 \\
\hline 108 & $440,613.7$ & $3,671,037.4$ & 44.0 \\
\hline 109 & $440,736.8$ & $3,671,013.0$ & 43.7 \\
\hline 110 & $440,623.5$ & $3,670,968.3$ & 44.4 \\
\hline 111 & $440,732.3$ & $3,670,938.4$ & 43.7 \\
\hline 112 & $440,624.1$ & $3,670,906.8$ & 43.2 \\
\hline 113 & $440,727.9$ & $3,670,885.5$ & 44.7 \\
\hline 114 & $440,723.6$ & $3,670,847.3$ & 41.8 \\
\hline 115 & $440,607.4$ & $3,670,782.3$ & 41.5 \\
\hline 116 & $440,586.1$ & $3,670,780.4$ & 41.7 \\
\hline 117 & $440,675.0$ & $3,670,772.1$ & 41.2 \\
\hline 118 & $440,658.8$ & $3,670,769.4$ & 41.1 \\
\hline
\end{tabular}


Table D-2. Location and Elevations of Vegetation Waste Units (continued)

\begin{tabular}{|c|c|c|c|}
\hline $\begin{array}{l}\text { Unit } \\
\text { ID No. }\end{array}$ & $\begin{array}{c}\text { Easting } \\
\text { UTM }\end{array}$ & $\begin{array}{c}\text { Northing } \\
\text { UTM }\end{array}$ & $\begin{array}{c}\text { Elevation } \\
\text { NAD27 }\end{array}$ \\
\hline 119 & $440,723.7$ & $3,670,656.3$ & 47.0 \\
\hline 120 & $440,812.7$ & $.3,670,622.8$ & 53.2 \\
\hline 121 & $440,560.6$ & $3,670,598.2$ & 46.4 \\
\hline 122 & $440,540.7$ & $3,670,528.1$ & 46.6 \\
\hline 123 & $440,873.9$ & $3,670,495.2$ & 54.2 \\
\hline 124 & $440,756.3$ & $3,670,456.6$ & 49.0 \\
\hline 125 & $440,738.6$ & $3,670,397.7$ & 47.1 \\
\hline 126 & $440,521.4$ & $3,670,388.0$ & 47.5 \\
\hline 127 & $440,486.2$ & $3,670,351.4$ & 48.6 \\
\hline 128 & $440,740.9$ & $3,670,302.4$ & 46.0 \\
\hline 129 & $440,462.2$ & $3,670,163.0$ & 46.2 \\
\hline 130 & $440,727.9$ & $3,670,164.5$ & 51.8 \\
\hline 131 & $440,690.2$ & $3,670,119.4$ & 50.1 \\
\hline 132 & $440,494.5$ & $3,670,048.6$ & 46.4 \\
\hline 133 & $440,673.6$ & $3,670,061.3$ & 46.1 \\
\hline 134 & $440,495.9$ & $3,669,996.2$ & 46.5 \\
\hline 135 & $440,684.9$ & $3,669,997.0$ & 44.2 \\
\hline 136 & $440,756.0$ & $3,669,963.3$ & 50.8 \\
\hline 137 & $440,531.9$ & $3,669,957.7$ & 44.4 \\
\hline 138 & $440,564.4$ & $3,669,911.9$ & 45.2 \\
\hline 139 & $440,782.2$ & $3,669,907.3$ & 51.1 \\
\hline 140 & $440,595.7$ & $3,669,905.0$ & 43.6 \\
\hline 141 & $440,597.8$ & $3,669,870.9$ & 45.1 \\
\hline 142 & $440,793.8$ & $3,669,849.2$ & 47.6 \\
\hline 143 & $440,605.5$ & $3,669,831.8$ & 46.0 \\
\hline 144 & $440,626.2$ & $3,669,798.4$ & 46.8 \\
\hline 145 & $440,665.8$ & $3,669,784.0$ & 44.2 \\
\hline 146 & $440,831.3$ & $3,669,779.2$ & 46.6 \\
\hline 147 & $440,884.7$ & $3,669,738.2$ & 44.1 \\
\hline 148 & $440,679.7$ & $3,669,712.5$ & 48.4 \\
\hline 149 & $440,962.4$ & $3,669,656.3$ & 42.7 \\
\hline 150 & $440,698.9$ & $3,669,653.0$ & 47.0 \\
\hline 151 & $440,749.9$ & $3,669,602.1$ & 44.0 \\
\hline
\end{tabular}


Table D-2. Location and Elevations of Vegetation Waste Units (continued)

\begin{tabular}{c|c|c|c}
\hline $\begin{array}{c}\text { Unit } \\
\text { ID No. }\end{array}$ & $\begin{array}{c}\text { Easting } \\
\text { UTM }\end{array}$ & $\begin{array}{c}\text { Northing } \\
\text { UTM }\end{array}$ & $\begin{array}{c}\text { Elevation } \\
\text { NAD27 }\end{array}$ \\
\hline 152 & $441,013.3$ & $3,669,557.9$ & 42.8 \\
153 & $440,896.2$ & $3,669,448.1$ & 41.9 \\
154 & $440,889.9$ & $3,669,386.0$ & 41.6 \\
155 & $440,903.0$ & $3,669,317.3$ & 42.0 \\
\hline
\end{tabular}

Table D-3. Location and Elevations of Ash Piles

\begin{tabular}{c|c|c|c}
\hline $\begin{array}{c}\text { Pile } \\
\text { ID No. }\end{array}$ & $\begin{array}{c}\text { Easting } \\
\text { UTM }\end{array}$ & $\begin{array}{c}\text { Northing } \\
\text { UTM }\end{array}$ & $\begin{array}{c}\text { Elevation } \\
\text { NAD27 }\end{array}$ \\
\hline 1 & $442,803.5$ & $3,674,130.1$ & 53.0 \\
2 & $442,748.7$ & $3,674,120.3$ & 52.7 \\
3 & $442,594.3$ & $3,674,103.8$ & 54.9 \\
4 & $442,667.6$ & $3,674,077.9$ & 51.7 \\
5 & $442,527.5$ & $3,674,081.2$ & 55.1 \\
6 & $442,350.3$ & $3,674,081.1$ & 54.8 \\
7 & $442,244.1$ & $3,674,046.8$ & 57.5 \\
8 & $442,604.0$ & $3,674,036.3$ & 54.7 \\
9 & $441,879.0$ & $3,674,024.7$ & 59.1 \\
10 & $442,454.7$ & $3,674,031.3$ & 55.2 \\
11 & $442,283.1$ & $3,674,019.6$ & 55.9 \\
12 & $442,111.9$ & $3,674,010.8$ & 57.1 \\
13 & $442,524.4$ & $3,673,974.6$ & 54.0 \\
14 & $442,566.3$ & $3,673,980.7$ & 53.2 \\
15 & $442,494.4$ & $3,673,953.2$ & 54.4 \\
16 & $442,022.1$ & $3,673,953.6$ & 55.8 \\
17 & $442,165.8$ & $3,673,951.5$ & 55.1 \\
18 & $442,149.9$ & $3,673,939.3$ & 55.2 \\
19 & $442,510.7$ & $3,673,941.7$ & 54.0 \\
20 & $442,300.1$ & $3,673,921.8$ & 54.8 \\
21 & $442,455.1$ & $3,673,916.7$ & 53.4 \\
22 & $442,492.4$ & $3,673,912.9$ & 53.8 \\
23 & $442,093.7$ & $3,673,870.8$ & 55.1 \\
24 & $442,426.8$ & $3,673,863.3$ & 53.8 \\
\hline
\end{tabular}


Table D-3. Location and Elevations of Ash Piles (continued)

\begin{tabular}{|c|c|c|c|}
\hline $\begin{array}{c}\text { Pile } \\
\text { ID No. }\end{array}$ & $\begin{array}{c}\text { Easting } \\
\text { UTM }\end{array}$ & $\begin{array}{l}\text { Northing } \\
\text { UTM }\end{array}$ & $\begin{array}{c}\text { Elevation } \\
\text { NAD27 }\end{array}$ \\
\hline 25 & $442,048.4$ & $3,673,862.5$ & 54.4 \\
\hline 26 & $442,465.1$ & . 3,673,854.0 & 52.8 \\
\hline 27 & $442,362.0$ & $3,673,854.2$ & 53.4 \\
\hline 28 & $441,785.9$ & $3,673,832.1$ & 54.7 \\
\hline 29 & $442,374.3$ & $3,673,831.9$ & 53.6 \\
\hline 30 & $442,232.7$ & $3,673,827.2$ & 53.7 \\
\hline 31 & $441,656.8$ & $3,673,823.7$ & 56.7 \\
\hline 32 & $442,636.1$ & $3,673,802.0$ & 54.5 \\
\hline 33 & $441,925.5$ & $3,673,798.4$ & 55.7 \\
\hline 34 & $441,693.0$ & $3,673,775.9$ & 54.9 \\
\hline 35 & $442,386.6$ & $3,673,797.0$ & 52.5 \\
\hline 36 & $442,410.8$ & $3,673,794.8$ & 52.2 \\
\hline 37 & $442,183.4$ & $3,673,789.5$ & 53.3 \\
\hline 38 & $441,873.1$ & $3,673,775.9$ & 53.8 \\
\hline 39 & $441,939.9$ & $3,673,737.6$ & 52.3 \\
\hline 40 & $442,130.1$ & $3,673,745.8$ & 52.7 \\
\hline 41 & $442,078.3$ & $3,673,733.8$ & 54.2 \\
\hline 42 & $441,849.3$ & $3,673,719.8$ & 52.7 \\
\hline 43 & $442,238.3$ & $3,673,715.0$ & 53.0 \\
\hline 44 & $441,725.3$ & $3,673,702.0$ & 55.5 \\
\hline 45 & $442,639.4$ & $3,673,691.7$ & 55.0 \\
\hline 46 & $442,326.2$ & $3,673,696.6$ & 51.8 \\
\hline 47 & $442,098.5$ & $3,673,691.9$ & 52.3 \\
\hline 48 & $441,877.8$ & $3,673,669.2$ & 52.0 \\
\hline 49 & $441,966.6$ & $3,673,657.7$ & 53.5 \\
\hline 50 & $441,918.6$ & $3,673,663.5$ & 52.7 \\
\hline 51 & $442,090.8$ & $3,673,651.9$ & 52.6 \\
\hline 52 & $441,719.3$ & $3,673,619.7$ & 54.3 \\
\hline 53 & $442,153.8$ & $3,673,624.6$ & 51.8 \\
\hline 54 & $441,371.2$ & $3,673,574.5$ & 57.2 \\
\hline 55 & $441,846.3$ & $3,673,567.8$ & 52.0 \\
\hline 56 & $441,881.9$ & $3,673,555.6$ & 52.3 \\
\hline 57 & $442,349.9$ & $3,673,563.8$ & 55.2 \\
\hline
\end{tabular}


Table D-3. Location and Elevations of Ash Piles (continued)

\begin{tabular}{|c|c|c|c|}
\hline $\begin{array}{c}\text { Pile } \\
\text { ID No. }\end{array}$ & $\begin{array}{c}\text { Easting } \\
\text { UTM }\end{array}$ & $\begin{array}{c}\text { Northing } \\
\text { UTM }\end{array}$ & $\begin{array}{c}\text { Elevation } \\
\text { NAD27 }\end{array}$ \\
\hline 58 & $441,723.7$ & $3,673,519.6$ & 54.0 \\
\hline 59 & $442,286.2$ & $3,673,522.2$ & 53.2 \\
\hline 60 & $441,848.0$ & $3,673,517.3$ & 52.4 \\
\hline 61 & $441,150.1$ & $3,673,514.6$ & 59.1 \\
\hline 62 & $441,891.7$ & $3,673,519.4$ & 51.2 \\
\hline 63 & $441,365.2$ & $3,673,515.4$ & 55.4 \\
\hline 64 & $441,140.9$ & $3,673,481.4$ & 56.8 \\
\hline 65 & $441,886.5$ & $3,673,485.9$ & 51.5 \\
\hline 66 & $441,168.2$ & $3,673,464.9$ & 55.4 \\
\hline 67 & $441,842.3$ & $3,673,483.4$ & 52.4 \\
\hline 68 & $441,340.4$ & $3,673,452.7$ & 55.1 \\
\hline 69 & $441,821.5$ & $3,673,454.3$ & 52.1 \\
\hline 70 & $441,135.2$ & $3,673,445.8$ & 56.1 \\
\hline 71 & $441,455.9$ & $3,673,448.7$ & 57.3 \\
\hline 72 & $441,443.6$ & $3,673,425.6$ & 57.1 \\
\hline 73 & $441,418.8$ & $3,673,414.5$ & 56.8 \\
\hline 74 & $441,836.6$ & $3,673,430.4$ & 51.7 \\
\hline 75 & $441,812.4$ & $3,673,398.8$ & 51.6 \\
\hline 76 & $441,706.2$ & $3,673,399.8$ & 53.9 \\
\hline 77 & $442,032.6$ & $3,673,398.8$ & 54.0 \\
\hline 78 & $441,151.1$ & $3,673,368.2$ & 54.7 \\
\hline 79 & $441,761.8$ & $3,673,368.3$ & 51.9 \\
\hline 80 & $441,728.8$ & $3,673,368.2$ & 52.5 \\
\hline 81 & $441,267.2$ & $3,673,342.7$ & 55.3 \\
\hline 82 & $441,090.2$ & $3,673,334.8$ & 57.0 \\
\hline 83 & $441,971.0$ & $3,673,327.5$ & 51.8 \\
\hline 84 & $441,231.5$ & $3,673,336.7$ & 54.3 \\
\hline 85 & $441,289.7$ & $3,673,317.9$ & 57.4 \\
\hline 86 & $441,074.3$ & $3,673,300.9$ & 56.9 \\
\hline 87 & $441,329.7$ & $3,673,312.6$ & 57.7 \\
\hline 88 & $441,113.4$ & $3,673,293.7$ & 54.2 \\
\hline 89 & $442,062.3$ & 3,673,298.2 & 56.6 \\
\hline 90 & $441,163.5$ & $3,673,286.4$ & 53.8 \\
\hline
\end{tabular}


Table D-3. Location and Elevations of Ash Piles (continued)

\begin{tabular}{c|c|c|c}
\hline $\begin{array}{c}\text { Pile } \\
\text { ID No. }\end{array}$ & $\begin{array}{c}\text { Easting } \\
\text { UTM }\end{array}$ & $\begin{array}{c}\text { Northing } \\
\text { UTM }\end{array}$ & $\begin{array}{c}\text { Elevation } \\
\text { NAD27 }\end{array}$ \\
\hline 91 & $441,395.7$ & $3,673,278.1$ & 57.8 \\
92 & $441,728.4$ & $3,673,280.8$ & 51.9 \\
93 & $441,116.1$ & $3,673,256.5$ & 54.5 \\
94 & $441,728.4$ & $3,673,259.9$ & 51.8 \\
95 & $441,249.7$ & $3,673,232.1$ & 54.5 \\
96 & $441,360.5$ & $3,673,253.5$ & 57.7 \\
97 & $441,738.7$ & $3,673,239.2$ & 51.2 \\
98 & $441,514.3$ & $3,673,238.9$ & 57.9 \\
99 & $441,689.3$ & $3,673,243.1$ & 52.4 \\
100 & $441,661.1$ & $3,673,220.1$ & 54.0 \\
101 & $441,702.3$ & $3,673,210.1$ & 51.5 \\
102 & $441,672.4$ & $3,673,194.2$ & 52.1 \\
103 & $441,613.5$ & $3,673,190.7$ & 55.9 \\
104 & $441,586.6$ & $3,673,191.1$ & 57.2 \\
105 & $441,129.7$ & $3,673,169.0$ & 52.9 \\
106 & $441,076.4$ & $3,673,162.4$ & 53.0 \\
107 & $441,228.3$ & $3,673,141.6$ & 54.2 \\
108 & $441,926.7$ & $3,673,144.7$ & 55.2 \\
109 & $441,507.2$ & $3,673,137.0$ & 56.1 \\
110 & $441,304.1$ & $3,673,140.6$ & 56.8 \\
111 & $441,129.7$ & $3,673,134.7$ & 52.6 \\
112 & $441,386.7$ & $3,673,104.3$ & 57.1 \\
113 & $441,046.2$ & $3,673,081.9$ & 54.7 \\
114 & $441,448.7$ & $3,673,080.5$ & 54.5 \\
115 & $441,152.2$ & $3,673,067.5$ & 51.3 \\
116 & $441,194.5$ & $3,673,049.4$ & 54.0 \\
117 & $441,404.4$ & $3,673,060.9$ & 55.4 \\
118 & $441,466.6$ & $3,673,026.6$ & 51.1 \\
119 & $441,038.3$ & $3,673,019.8$ & 53.0 \\
120 & $441,151.9$ & $3,673,011.9$ & 51.3 \\
121 & $441,368.2$ & $3,673,005.6$ & 54.0 \\
122 & $441,053.7$ & $3,672,992.0$ & 52.6 \\
123 & $441,203.5$ & $3,672,983.6$ & 54.6 \\
\hline & & &
\end{tabular}


Table D-3. Location and Elevations of Ash Piles (continued)

\begin{tabular}{|c|c|c|c|}
\hline $\begin{array}{c}\text { Pile } \\
\text { ID No. }\end{array}$ & $\begin{array}{c}\text { Easting } \\
\text { UTM }\end{array}$ & $\begin{array}{l}\text { Northing } \\
\text { UTM }\end{array}$ & $\begin{array}{c}\text { Elevation } \\
\text { NAD27 }\end{array}$ \\
\hline 124 & $441,338.5$ & $3,672,979.0$ & 51.7 \\
\hline 125 & $440,912.8$ & $3,672,982.0$ & 59.0 \\
\hline 126 & $441,653.9$ & $3,672,980.3$ & 55.3 \\
\hline 127 & $441,622.2$ & $3,672,976.4$ & 55.0 \\
\hline 128 & $441,019.2$ & $3,672,974.5$ & 54.7 \\
\hline 129 & $441,609.2$ & $3,672,949.5$ & 55.4 \\
\hline 130 & $441,153.1$ & $3,672,953.0$ & 52.1 \\
\hline 131 & $441,174.7$ & $3,672,947.7$ & 52.6 \\
\hline 132 & $440,846.8$ & $3,672,938.2$ & 58.2 \\
\hline 133 & $440,886.6$ & $3,672,944.0$ & 56.9 \\
\hline 134 & $441,344.6$ & $3,672,944.2$ & 51.3 \\
\hline 135 & $441,581.8$ & $3,672,919.2$ & 56.6 \\
\hline 136 & $440,886.9$ & $3,672,912.7$ & 54.3 \\
\hline 137 & $441,661.2$ & $3,672,918.8$ & 57.1 \\
\hline 138 & $440,859.3$ & $3,672,921.6$ & 57.1 \\
\hline 139 & $441,281.4$ & $3,672,914.1$ & 51.7 \\
\hline 140 & $441,125.6$ & $3,672,908.1$ & 51.5 \\
\hline 141 & $441,601.5$ & $3,672,895.1$ & 58.8 \\
\hline 142 & $441,698.0$ & $3,672,887.3$ & 58.2 \\
\hline 143 & $441,113.2$ & $3,672,878.9$ & 51.4 \\
\hline 144 & $440,856.5$ & $3,672,840.5$ & 58.1 \\
\hline 145 & $441,515.0$ & $3,672,811.4$ & 56.2 \\
\hline 146 & $440,906.5$ & $3,672,792.0$ & 53.6 \\
\hline 147 & $440,846.8$ & $3,672,774.6$ & 54.2 \\
\hline 148 & $441,001.9$ & $3,672,781.4$ & 50.8 \\
\hline 149 & $441,237.4$ & $3,672,775.7$ & 54.8 \\
\hline 150 & $441,276.4$ & $3,672,756.9$ & 56.2 \\
\hline 151 & $441,383.4$ & $3,672,753.8$ & 57.0 \\
\hline 152 & $441,253.4$ & $3,672,758.6$ & 56.1 \\
\hline 153 & $441,177.8$ & $3,672,734.3$ & 55.2 \\
\hline 154 & $440,793.4$ & $3,672,736.1$ & 59.8 \\
\hline 155 & $441,267.3$ & $3,672,721.8$ & 57.8 \\
\hline 156 & $441,187.7$ & $3,672,705.5$ & 57.2 \\
\hline
\end{tabular}


Table D-3. Location and Elevations of Ash Piles (continued)

\begin{tabular}{|c|c|c|c|}
\hline $\begin{array}{c}\text { Pile } \\
\text { ID No. }\end{array}$ & $\begin{array}{c}\text { Easting } \\
\text { UTM }\end{array}$ & $\begin{array}{c}\text { Northing } \\
\text { UTM }\end{array}$ & $\begin{array}{c}\text { Elevation } \\
\text { NAD27 }\end{array}$ \\
\hline 157 & $440,817.4$ & $3,672,707.2$ & 54.4 \\
\hline 158 & $441,301.2$ & $3,672,700.5$ & 58.6 \\
\hline 159 & $441,221.9$ & $3,672,695.1$ & 59.1 \\
\hline 160 & $440,836.4$ & $3,672,649.4$ & 53.4 \\
\hline 161 & $440,929.3$ & $3,672,617.4$ & 50.4 \\
\hline 162 & $440,737.7$ & $3,672,579.7$ & 59.4 \\
\hline 163 & $440,715.2$ & $3,672,576.2$ & 59.8 \\
\hline 164 & $440,774.9$ & $3,672,568.2$ & 59.0 \\
\hline 165 & $440,858.6$ & $3,672,531.4$ & 53.7 \\
\hline 166 & $440,897.3$ & $3,672,525.0$ & 51.0 \\
\hline 167 & $440,635.3$ & $3,672,482.1$ & 59.0 \\
\hline 168 & $440,723.6$ & $3,672,470.4$ & 57.0 \\
\hline 169 & $440,891.2$ & $3,672,454.2$ & 50.5 \\
\hline 170 & $440,711.4$ & $3,672,446.3$ & 57.4 \\
\hline 171 & $440,791.1$ & $3,672,430.6$ & 57.2 \\
\hline 172 & $440,640.4$ & $3,672,425.3$ & 58.4 \\
\hline 173 & $440,941.0$ & $3,672,410.3$ & 49.2 \\
\hline 174 & $441,071.2$ & $3,672,407.8$ & 57.1 \\
\hline 175 & $440,700.5$ & $3,672,394.5$ & 57.4 \\
\hline 176 & $440,735.0$ & $3,672,368.5$ & 56.5 \\
\hline 177 & $440,586.5$ & $3,672,342.6$ & 57.8 \\
\hline 178 & $440,641.1$ & $3,672,340.6$ & 56.1 \\
\hline 179 & $440,696.5$ & $3,672,336.0$ & 55.9 \\
\hline 180 & $441,139.8$ & $3,672,289.3$ & 58.4 \\
\hline 181 & $440,291.4$ & $3,672,298.9$ & 61.6 \\
\hline 182 & $440,337.3$ & $3,672,288.3$ & 60.2 \\
\hline 183 & $440,452.9$ & $3,672,270.7$ & 60.3 \\
\hline 184 & $440,366.6$ & $3,672,272.4$ & 60.3 \\
\hline 185 & $440,498.2$ & $3,672,254.0$ & 58.6 \\
\hline 186 & $440,744.5$ & $3,672,257.6$ & 55.0 \\
\hline 187 & $441,211.1$ & $3,672,254.6$ & 59.5 \\
\hline 188 & $440,774.6$ & $3,672,249.2$ & 55.2 \\
\hline 189 & $441,154.3$ & $3,672,250.0$ & 58.2 \\
\hline
\end{tabular}


Table D-3. Location and Elevations of Ash Piles (continued)

\begin{tabular}{|c|c|c|c|}
\hline $\begin{array}{c}\text { Pile } \\
\text { ID No. }\end{array}$ & $\begin{array}{c}\text { Easting } \\
\text { UTM }\end{array}$ & $\begin{array}{c}\text { Northing } \\
\text { UTM }\end{array}$ & $\begin{array}{l}\text { Elevation } \\
\text { NAD27 }\end{array}$ \\
\hline 190 & $440,606.8$ & $3,672,242.0$ & 55.0 \\
\hline 191 & $440,680.5$ & $3,672,246.2$ & 55.6 \\
\hline 192 & $441,113.7$ & $3,672,228.9$ & 53.4 \\
\hline 193 & $440,548.1$ & $3,672,239.4$ & 56.7 \\
\hline 194 & $441,200.7$ & $3,672,229.1$ & 56.6 \\
\hline 195 & $440,889.9$ & $3,672,214.3$ & 50.9 \\
\hline 196 & $440,496.9$ & $3,672,205.7$ & 57.2 \\
\hline 197 & $440,628.9$ & $3,672,209.4$ & 52.8 \\
\hline 198 & $441,163.0$ & $3,672,208.7$ & 54.2 \\
\hline 199 & $440,568.3$ & $3,672,196.1$ & 53.8 \\
\hline 200 & $440,364.1$ & $3,672,196.0$ & 57.3 \\
\hline 201 & $440,748.9$ & $3,672,172.2$ & 52.0 \\
\hline 202 & $440,833.2$ & $3,672,172.9$ & 50.7 \\
\hline 203 & $440,905.7$ & $3,672,153.6$ & 48.4 \\
\hline 204 & $440,317.1$ & $3,672,178.4$ & 58.4 \\
\hline 205 & $440,691.9$ & $3,672,165.5$ & 52.4 \\
\hline 206 & $440,422.7$ & $3,672,168.1$ & 56.4 \\
\hline 207 & $440,406.2$ & $3,672,157.7$ & 55.6 \\
\hline 208 & $440,465.2$ & $3,672,153.6$ & 55.4 \\
\hline 209 & $440,328.4$ & $3,672,154.3$ & 59.2 \\
\hline 210 & $440,432.6$ & $3,672,154.3$ & 55.4 \\
\hline 211 & $440,860.0$ & $3,672,146.7$ & 49.8 \\
\hline 212 & $441,153.2$ & $3,672,127.3$ & 51.7 \\
\hline 213 & $440,640.4$ & $3,672,105.6$ & 51.3 \\
\hline 214 & $440,802.4$ & $3,672,104.4$ & 50.4 \\
\hline 215 & $440,707.3$ & $3,672,103.3$ & 50.8 \\
\hline 216 & $440,560.4$ & $3,672,104.4$ & 50.7 \\
\hline 217 & $440,513.7$ & $3,672,097.7$ & 50.8 \\
\hline 218 & $441,199.2$ & $3,672,083.9$ & 56.7 \\
\hline 219 & $440,614.4$ & $3,672,075.7$ & 49.4 \\
\hline 220 & $440,671.5$ & $3,672,041.2$ & 49.8 \\
\hline 221 & $440,476.2$ & $3,672,058.7$ & 51.0 \\
\hline 222 & $440,544.3$ & $3,672,071.1$ & 48.4 \\
\hline
\end{tabular}


Table D-3. Location and Elevations of Ash Piles (continued)

\begin{tabular}{|c|c|c|c|}
\hline $\begin{array}{c}\text { Pile } \\
\text { ID No. }\end{array}$ & $\begin{array}{c}\text { Easting } \\
\text { UTM }\end{array}$ & $\begin{array}{c}\text { Northing } \\
\text { UTM }\end{array}$ & $\begin{array}{c}\text { Elevation } \\
\text { NAD27 }\end{array}$ \\
\hline 223 & $440,635.4$ & $3,672,049.1$ & 49.6 \\
\hline 224 & $441,197.4$ & $.3,672,065.8$ & 56.0 \\
\hline 225 & $441,143.5$ & $3,672,052.9$ & 52.3 \\
\hline 226 & $440,443.4$ & $3,672,039.1$ & 53.0 \\
\hline 227 & $440,843.5$ & $3,672,027.2$ & 47.4 \\
\hline 228 & $440,517.7$ & $3,672,019.6$ & 49.0 \\
\hline 229 & $441,206.3$ & $3,672,029.0$ & 49.7 \\
\hline 230 & $440,800.2$ & $3,672,018.7$ & 48.0 \\
\hline 231 & $440,735.3$ & $3,672,007.1$ & 48.5 \\
\hline 232 & $440,439.5$ & $3,671,991.4$ & 52.8 \\
\hline 233 & $441,084.2$ & $3,671,994.6$ & 48.7 \\
\hline 234 & $440,843.2$ & $3,671,978.0$ & 46.6 \\
\hline 235 & $441,326.3$ & $3,671,977.9$ & 52.4 \\
\hline 236 & $441,199.5$ & $3,671,965.3$ & 52.9 \\
\hline 237 & $441,293.3$ & $3,671,962.0$ & 52.8 \\
\hline 238 & $440,358.5$ & $3,671,967.8$ & 55.4 \\
\hline 239 & $440,509.9$ & $3,671,941.6$ & 49.1 \\
\hline 240 & $441,366.7$ & $3,671,968.4$ & 55.6 \\
\hline 241 & $441,265.2$ & $3,671,957.2$ & 52.6 \\
\hline 242 & $440,804.8$ & $3,671,952.6$ & 47.3 \\
\hline 243 & $440,362.8$ & $3,671,950.9$ & 53.1 \\
\hline 244 & $440,286.4$ & $3,671,941.5$ & 59.0 \\
\hline 245 & $441,336.5$ & $3,671,945.1$ & 52.4 \\
\hline 246 & $440,761.4$ & $3,671,934.3$ & 47.2 \\
\hline 247 & $441,046.6$ & $3,671,937.2$ & 50.2 \\
\hline 248 & $440,529.8$ & $3,671,940.1$ & 47.9 \\
\hline 249 & $440,781.5$ & $3,671,936.5$ & 47.3 \\
\hline 250 & $440,729.0$ & $3,671,924.7$ & 47.5 \\
\hline 251 & $441,410.6$ & $3,671,928.4$ & 55.9 \\
\hline 252 & $441,179.2$ & $3,671,926.4$ & 54.4 \\
\hline 253 & $441,355.0$ & $3,671,927.2$ & 54.8 \\
\hline 254 & $441,253.1$ & $3,671,925.5$ & 54.4 \\
\hline 255 & $441,087.0$ & $3,671,923.5$ & 52.0 \\
\hline
\end{tabular}


Table D-3. Location and Elevations of Ash Piles (continued)

\begin{tabular}{|c|c|c|c|}
\hline $\begin{array}{c}\text { Pile } \\
\text { ID No. }\end{array}$ & $\begin{array}{c}\text { Easting } \\
\text { UTM }\end{array}$ & $\begin{array}{c}\text { Northing } \\
\text { UTM }\end{array}$ & $\begin{array}{c}\text { Elevation } \\
\text { NAD27 }\end{array}$ \\
\hline 256 & $440,336.7$ & $3,671,911.6$ & 52.8 \\
\hline 257 & $441,122.8$ & $3,671,921.9$ & 53.7 \\
\hline 258 & $440,434.3$ & $3,671,921.2$ & 50.7 \\
\hline 259 & $440,828.9$ & $3,671,908.7$ & 46.8 \\
\hline 260 & $441,037.6$ & $3,671,909.3$ & 49.9 \\
\hline 261 & $440,245.8$ & $3,671,903.3$ & 58.7 \\
\hline 262 & $440,454.6$ & $3,671,903.2$ & 49.8 \\
\hline 263 & $440,363.9$ & $3,671,911.5$ & 51.7 \\
\hline 264 & $440,498.8$ & $3,671,894.9$ & 48.4 \\
\hline 265 & $440,704.1$ & $3,671,907.9$ & 47.4 \\
\hline 266 & $440,670.6$ & $3,671,896.8$ & 47.5 \\
\hline 267 & $441,167.9$ & $3,671,895.3$ & 55.4 \\
\hline 268 & $441,265.7$ & $3,671,893.3$ & 55.9 \\
\hline 269 & $440,357.0$ & $3,671,876.8$ & 51.2 \\
\hline 270 & $440,744.0$ & $3,671,881.4$ & 47.9 \\
\hline 271 & $440,277.0$ & $3,671,867.5$ & 57.5 \\
\hline 272 & $440,643.1$ & $3,671,879.3$ & 47.9 \\
\hline 273 & $440,678.5$ & $3,671,868.4$ & 47.9 \\
\hline 274 & $441,259.4$ & $3,671,875.2$ & 56.3 \\
\hline 275 & $440,349.2$ & $3,671,848.1$ & 51.7 \\
\hline 276 & $440,648.9$ & $3,671,860.4$ & 48.3 \\
\hline 277 & $441,014.6$ & $3,671,857.6$ & 51.2 \\
\hline 278 & $440,798.9$ & $3,671,852.4$ & 46.6 \\
\hline 279 & $441,442.6$ & $3,671,842.0$ & 58.6 \\
\hline 280 & $441,306.0$ & $3,671,848.9$ & 57.6 \\
\hline 281 & $441,243.4$ & $3,671,846.4$ & 57.6 \\
\hline 282 & $441,419.3$ & $3,671,839.2$ & 58.5 \\
\hline 283 & $441,527.7$ & $3,671,843.1$ & 61.4 \\
\hline 284 & $440,675.1$ & $3,671,835.3$ & 47.4 \\
\hline 285 & $440,624.0$ & $3,671,834.3$ & 47.3 \\
\hline 286 & $441,503.7$ & $3,671,825.5$ & 58.9 \\
\hline 287 & $441,336.4$ & $3,671,827.4$ & 57.1 \\
\hline 288 & $441,471.1$ & $3,671,821.2$ & 58.5 \\
\hline
\end{tabular}


Table D-3. Location and Elevations of Ash Piles (continued)

\begin{tabular}{|c|c|c|c|}
\hline $\begin{array}{c}\text { Pile } \\
\text { ID No. }\end{array}$ & $\begin{array}{c}\text { Easting } \\
\text { UTM }\end{array}$ & $\begin{array}{c}\text { Northing } \\
\text { UTM }\end{array}$ & $\begin{array}{c}\text { Elevation } \\
\text { NAD27 }\end{array}$ \\
\hline 289 & $440,757.4$ & $3,671,808.9$ & 46.6 \\
\hline 290 & $441,051.6$ & $3,671,816.1$ & 52.6 \\
\hline 291 & $440,670.8$ & $3,671,818.9$ & 46.7 \\
\hline 292 & $441,119.6$ & $3,671,812.4$ & 55.0 \\
\hline 293 & $440,196.8$ & $3,671,817.4$ & 59.7 \\
\hline 294 & $441,175.3$ & $3,671,807.8$ & 55.3 \\
\hline 295 & $440,331.9$ & $3,671,798.5$ & 53.0 \\
\hline 296 & $441,432.3$ & $3,671,808.0$ & 57.3 \\
\hline 297 & $440,641.6$ & $3,671,807.9$ & 47.2 \\
\hline 298 & $440,355.2$ & $3,671,759.7$ & 53.8 \\
\hline 299 & $440,250.8$ & $3,671,778.5$ & 57.3 \\
\hline 300 & $440,428.2$ & $3,671,782.2$ & 50.0 \\
\hline 301 & $441,498.2$ & $3,671,795.6$ & 63.5 \\
\hline 302 & $440,630.1$ & $3,671,794.8$ & 46.3 \\
\hline 303 & $441,382.2$ & $3,671,785.8$ & 56.7 \\
\hline 304 & $440,933.4$ & $3,671,783.0$ & 46.6 \\
\hline 305 & $441,369.4$ & $3,671,777.6$ & 56.1 \\
\hline 306 & $441,541.1$ & $3,671,784.1$ & 59.9 \\
\hline 307 & $440,160.2$ & $3,671,777.1$ & 59.8 \\
\hline 308 & $440,625.1$ & $3,671,780.5$ & 46.1 \\
\hline 309 & $441,236.3$ & $3,671,762.2$ & 53.3 \\
\hline 310 & $440,294.8$ & $3,671,744.7$ & 56.0 \\
\hline 311 & $440,332.6$ & $3,671,753.1$ & 54.7 \\
\hline 312 & $440,609.8$ & $3,671,760.0$ & 46.3 \\
\hline 313 & $440,551.4$ & $3,671,755.3$ & 46.7 \\
\hline 314 & $441,303.7$ & $3,671,751.2$ & 55.1 \\
\hline 315 & $441,377.8$ & $3,671,745.8$ & 57.7 \\
\hline 316 & $440,619.5$ & $3,671,744.1$ & 46.2 \\
\hline 317 & $440,713.2$ & $3,671,718.7$ & 46.1 \\
\hline 318 & $440,624.4$ & $3,671,729.9$ & 46.6 \\
\hline 319 & $441,030.7$ & $3,671,721.5$ & 49.4 \\
\hline 320 & $440,426.5$ & $3,671,709.8$ & 49.0 \\
\hline 321 & $440,534.6$ & $3,671,719.8$ & 47.5 \\
\hline
\end{tabular}


Table D-3. Location and Elevations of Ash Piles (continued)

\begin{tabular}{|c|c|c|c|}
\hline $\begin{array}{c}\text { Pile } \\
\text { ID No. }\end{array}$ & $\begin{array}{c}\text { Easting } \\
\text { UTM }\end{array}$ & $\begin{array}{l}\text { Northing } \\
\text { UTM }\end{array}$ & $\begin{array}{c}\text { Elevation } \\
\text { NAD27 }\end{array}$ \\
\hline 322 & $440,558.9$ & $3,671,716.4$ & 46.8 \\
\hline 323 & $440,920.4$ & $3,671,710.3$ & 47.8 \\
\hline 324 & $441,064.4$ & $3,671,708.1$ & 51.5 \\
\hline 325 & $440,527.9$ & $3,671,695.2$ & 47.3 \\
\hline 326 & $441,291.9$ & $3,671,686.2$ & 56.2 \\
\hline 327 & $440,563.8$ & $3,671,679.0$ & 46.2 \\
\hline 328 & $440,995.2$ & $3,671,676.3$ & 51.1 \\
\hline 329 & $441,265.5$ & $3,671,681.0$ & 56.6 \\
\hline 330 & $440,934.5$ & $3,671,684.8$ & 50.4 \\
\hline 331 & $441,149.3$ & $3,671,680.5$ & 53.0 \\
\hline 332 & $441,349.3$ & $3,671,680.7$ & 59.1 \\
\hline 333 & $441,202.5$ & $3,671,678.5$ & 55.2 \\
\hline 334 & $440,643.9$ & $3,671,648.0$ & 46.0 \\
\hline 335 & $441,324.6$ & $3,671,672.7$ & 57.8 \\
\hline 336 & $440,536.8$ & $3,671,663.5$ & 47.1 \\
\hline 337 & $440,896.3$ & $3,671,664.2$ & 53.1 \\
\hline 338 & $440,948.4$ & $3,671,663.7$ & 51.1 \\
\hline 339 & $441,264.8$ & $3,671,648.8$ & 58.0 \\
\hline 340 & $441,094.2$ & $3,671,648.5$ & 54.3 \\
\hline 341 & $441,361.7$ & $3,671,637.0$ & 58.3 \\
\hline 342 & $441,193.3$ & $3,671,639.1$ & 56.3 \\
\hline 343 & $441,249.2$ & $3,671,641.8$ & 57.3 \\
\hline 344 & $440,886.4$ & $3,671,634.3$ & 53.3 \\
\hline 345 & $441,007.1$ & $3,671,633.7$ & 52.7 \\
\hline 346 & $441,037.9$ & $3,671,629.4$ & 53.3 \\
\hline 347 & $440,912.1$ & $3,671,619.3$ & 53.0 \\
\hline 348 & $440,990.8$ & $3,671,618.8$ & 53.0 \\
\hline 349 & $440,258.8$ & $3,671,605.7$ & 58.6 \\
\hline 350 & $440,965.5$ & $3,671,595.4$ & 53.7 \\
\hline 351 & $440,417.5$ & $3,671,579.1$ & 49.8 \\
\hline 352 & $440,995.1$ & $3,671,591.8$ & 53.7 \\
\hline 353 & $440,590.7$ & $3,671,600.1$ & 45.5 \\
\hline 354 & $440,441.3$ & $3,671,578.3$ & 48.7 \\
\hline
\end{tabular}


Table D-3. Location and Elevations of Ash Piles (continued)

\begin{tabular}{|c|c|c|c|}
\hline $\begin{array}{c}\text { Pile } \\
\text { ID No. }\end{array}$ & $\begin{array}{c}\text { Easting } \\
\text { UTM }\end{array}$ & $\begin{array}{c}\text { Northing } \\
\text { UTM }\end{array}$ & $\begin{array}{c}\text { Elevation } \\
\text { NAD27 }\end{array}$ \\
\hline 355 & $440,593.0$ & $3,671,581.1$ & 45.2 \\
\hline 356 & $440,260.3$ & $3,671,579.2$ & 58.9 \\
\hline 357 & $440,330.8$ & $3,671,571.9$ & 55.3 \\
\hline 358 & $441,198.0$ & $3,671,569.9$ & 58.0 \\
\hline 359 & $440,314.5$ & $3,671,546.8$ & 56.0 \\
\hline 360 & $441,070.5$ & $3,671,548.3$ & 56.0 \\
\hline 361 & $440,647.2$ & $3,671,532.6$ & 44.1 \\
\hline 362 & $441,091.3$ & $3,671,534.0$ & 56.8 \\
\hline 363 & $440,370.4$ & $3,671,535.7$ & 54.5 \\
\hline 364 & $440,887.8$ & $3,671,526.9$ & 56.1 \\
\hline 365 & $441,012.3$ & $3,671,519.2$ & 56.4 \\
\hline 366 & $441,252.5$ & $3,671,524.1$ & 60.3 \\
\hline 367 & $441,081.3$ & $3,671,511.9$ & 56.6 \\
\hline 368 & $440,647.4$ & $3,671,491.9$ & 44.5 \\
\hline 369 & $440,419.2$ & $3,671,492.8$ & 52.0 \\
\hline 370 & $441,143.7$ & $3,671,509.0$ & 57.2 \\
\hline 371 & $441,110.1$ & $3,671,505.7$ & 56.9 \\
\hline 372 & $441,231.6$ & $3,671,495.1$ & 58.6 \\
\hline 373 & $440,352.7$ & $3,671,501.1$ & 55.6 \\
\hline 374 & $440,815.8$ & $3,671,503.8$ & 55.3 \\
\hline 375 & $440,924.0$ & $3,671,488.8$ & 56.2 \\
\hline 376 & $440,967.9$ & $3,671,492.7$ & 56.5 \\
\hline 377 & $441,122.1$ & $3,671,499.6$ & 56.8 \\
\hline 378 & $441,068.2$ & $3,671,485.2$ & 56.5 \\
\hline 379 & $440,769.6$ & $3,671,476.0$ & 53.8 \\
\hline 380 & $441,172.6$ & $3,671,489.6$ & 57.1 \\
\hline 381 & $440,816.6$ & $3,671,476.9$ & 55.4 \\
\hline 382 & $441,259.4$ & $3,671,472.1$ & 59.8 \\
\hline 383 & $440,618.5$ & $3,671,453.8$ & 45.2 \\
\hline 384 & $441,139.2$ & $3,671,460.6$ & 56.9 \\
\hline 385 & $440,853.5$ & $3,671,461.2$ & 55.2 \\
\hline 386 & $440,820.1$ & $3,671,447.7$ & 54.7 \\
\hline 387 & $440,455.4$ & $3,671,440.7$ & 50.7 \\
\hline
\end{tabular}


Table D-3. Location and Elevations of Ash Piles (continued)

\begin{tabular}{|c|c|c|c|}
\hline $\begin{array}{c}\text { Pile } \\
\text { ID No. }\end{array}$ & $\begin{array}{c}\text { Easting } \\
\text { UTM }\end{array}$ & $\begin{array}{c}\text { Northing } \\
\text { UTM }\end{array}$ & $\begin{array}{c}\text { Elevation } \\
\text { NAD27 }\end{array}$ \\
\hline 388 & $440,371.6$ & $3,671,436.9$ & 56.1 \\
\hline 389 & $441,197.3$ & $3,671,432.4$ & 58.0 \\
\hline 390 & $440,748.6$ & $3,671,435.1$ & 51.6 \\
\hline 391 & $440,261.9$ & $3,671,428.6$ & 59.8 \\
\hline 392 & $440,323.6$ & $3,671,412.5$ & 57.8 \\
\hline 393 & $440,779.5$ & $3,671,421.2$ & 52.0 \\
\hline 394 & $440,962.5$ & $3,671,413.6$ & 53.0 \\
\hline 395 & $440,282.7$ & $3,671,396.7$ & 59.5 \\
\hline 396 & $440,884.5$ & $3,671,406.4$ & 51.2 \\
\hline 397 & $441,200.0$ & $3,671,393.4$ & 57.8 \\
\hline 398 & $440,735.4$ & $3,671,386.0$ & 48.1 \\
\hline 399 & $440,345.7$ & $3,671,380.3$ & 56. \\
\hline 400 & $441,064.9$ & $3,671,390.9$ & 55.3 \\
\hline 401 & $440,416.0$ & $3,671,384.4$ & 52.2 \\
\hline 402 & $441,115.8$ & $3,671,387.1$ & 56.9 \\
\hline 403 & $441,096.0$ & $3,671,371.2$ & 56.5 \\
\hline 404 & $441,180.4$ & $3,671,377.2$ & 57.6 \\
\hline 405 & $441,045.5$ & $3,671,368.3$ & 54.3 \\
\hline 406 & $441,194.6$ & $3,671,368.0$ & 58.0 \\
\hline 407 & $440,822.7$ & $3,671,358.8$ & 49.0 \\
\hline 408 & $440,996.9$ & $3,671,350.5$ & 52.7 \\
\hline 409 & $440,412.8$ & $3,671,364.0$ & 52.0 \\
\hline 410 & $440,937.8$ & $3,671,348.4$ & 50.2 \\
\hline 411 & $440,977.7$ & $3,671,351.3$ & 52.5 \\
\hline 412 & $440,726.7$ & $3,671,341.9$ & 45.4 \\
\hline 413 & $440,368.6$ & $3,671,337.7$ & 54.6 \\
\hline 414 & $441,210.2$ & $3,671,327.8$ & 58.0 \\
\hline 415 & $440,966.1$ & $3,671,323.7$ & 52.7 \\
\hline 416 & $441,107.4$ & $3,671,325.7$ & 56.9 \\
\hline 417 & $441,174.2$ & $3,671,321.4$ & 58.1 \\
\hline 418 & $440,723.6$ & $3,671,309.7$ & 45.7 \\
\hline 419 & $440,417.9$ & $3,671,313.2$ & 53.5 \\
\hline 420 & $440,983.8$ & $3,671,303.8$ & 53.4 \\
\hline
\end{tabular}


Table D-3. Location and Elevations of Ash Piles (continued)

\begin{tabular}{|c|c|c|c|}
\hline $\begin{array}{c}\text { Pile } \\
\text { ID No. }\end{array}$ & $\begin{array}{c}\text { Easting } \\
\text { UTM }\end{array}$ & $\begin{array}{c}\text { Northing } \\
\text { UTM }\end{array}$ & $\begin{array}{c}\text { Elevation } \\
\text { NAD27 }\end{array}$ \\
\hline 421 & $441,116.4$ & $3,671,302.3$ & 57.4 \\
\hline 422 & $441,043.0$ & $3,671,301.9$ & 55.1 \\
\hline 423 & $440,709.2$ & $3,671,290.4$ & 45.6 \\
\hline 424 & $440,326.6$ & $3,671,284.3$ & 57.8 \\
\hline 425 & $441,065.4$ & $3,671,290.6$ & 55.8 \\
\hline 426 & $441,088.4$ & $3,671,284.6$ & 56.7 \\
\hline 427 & $441,211.9$ & $3,671,286.9$ & 58.7 \\
\hline 428 & $440,395.3$ & $3,671,258.9$ & 55.0 \\
\hline 429 & $440,746.5$ & $3,671,270.5$ & 45.4 \\
\hline 430 & $440,712.7$ & $3,671,259.3$ & 45.5 \\
\hline 431 & $440,467.7$ & $3,671,248.7$ & 52.5 \\
\hline 432 & $440,914.9$ & $3,671,247.4$ & 48.9 \\
\hline 433 & $440,356.6$ & $3,671,246.7$ & 57.1 \\
\hline 434 & $440,761.6$ & $3,671,256.7$ & 45.3 \\
\hline 435 & $440,281.8$ & $3,671,241.9$ & 60.1 \\
\hline 436 & $440,691.6$ & $3,671,250.0$ & 45.3 \\
\hline 437 & $440,965.8$ & $3,671,239.1$ & 53.6 \\
\hline 438 & $440,989.5$ & $3,671,227.9$ & 54.3 \\
\hline 439 & $440,749.8$ & $3,671,228.8$ & 44.7 \\
\hline 440 & $440,707.8$ & $3,671,205.2$ & 44.6 \\
\hline 441 & $440,956.0$ & $3,671,194.7$ & 53.7 \\
\hline 442 & $440,727.0$ & $3,671,206.0$ & 44.7 \\
\hline 443 & $440,923.8$ & $3,671,207.3$ & 51.4 \\
\hline 444 & $440,468.6$ & $3,671,195.8$ & 53.6 \\
\hline 445 & $440,394.8$ & $3,671,199.5$ & 56.6 \\
\hline 446 & $441,002.8$ & $3,671,195.4$ & 56.9 \\
\hline 447 & $440,845.7$ & $3,671,184.5$ & 48.0 \\
\hline 448 & $440,863.7$ & $3,671,177.8$ & 49.0 \\
\hline 449 & $440,490.3$ & $3,671,170.3$ & 54.0 \\
\hline 450 & $440,942.7$ & $3,671,150.3$ & 55.9 \\
\hline 451 & $441,002.6$ & $3,671,150.0$ & 59.3 \\
\hline 452 & $440,535.9$ & $3,671,130.1$ & 52.1 \\
\hline 453 & $440,891.8$ & $3,671,141.6$ & 52.6 \\
\hline
\end{tabular}


Table D-3. Location and Elevations of Ash Piles (continued)

\begin{tabular}{c|c|c|c}
\hline $\begin{array}{c}\text { Pile } \\
\text { ID No. }\end{array}$ & $\begin{array}{c}\text { Easting } \\
\text { UTM }\end{array}$ & $\begin{array}{c}\text { Northing } \\
\text { UTM }\end{array}$ & $\begin{array}{c}\text { Elevation } \\
\text { NAD27 }\end{array}$ \\
\hline 454 & $440,392.2$ & $3,671,139.4$ & 58.6 \\
455 & $440,779.7$ & $3,671,139.7$ & 45.9 \\
456 & $440,993.6$ & $3,671,133.6$ & 59.2 \\
457 & $440,730.9$ & $3,671,117.3$ & 44.5 \\
458 & $440,883.1$ & $3,671,119.8$ & 53.6 \\
459 & $440,402.8$ & $3,671,100.5$ & 58.3 \\
460 & $440,501.0$ & $3,671,115.2$ & 54.4 \\
461 & $440,743.8$ & $3,671,104.0$ & 44.3 \\
462 & $440,456.2$ & $3,671,109.0$ & 55.3 \\
463 & $440,702.7$ & $3,671,111.2$ & 43.9 \\
464 & $440,876.9$ & $3,671,097.5$ & 53.8 \\
465 & $440,824.9$ & $3,671,088.4$ & 48.8 \\
466 & $440,538.6$ & $3,671,086.5$ & 52.7 \\
467 & $440,387.5$ & $3,671,065.6$ & 60.3 \\
468 & $440,501.0$ & $3,671,069.3$ & 53.3 \\
469 & $440,480.9$ & $3,671,059.9$ & 54.4 \\
470 & $440,567.7$ & $3,671,045.6$ & 50.9 \\
471 & $440,518.7$ & $3,671,044.7$ & 52.4 \\
472 & $440,837.0$ & $3,671,027.4$ & 49.0 \\
473 & $440,551.5$ & $3,671,023.3$ & 50.1 \\
474 & $440,905.7$ & $3,671,022.4$ & 55.3 \\
475 & $440,484.4$ & $3,671,006.7$ & 52.8 \\
476 & $440,827.4$ & $3,671,007.0$ & 47.2 \\
477 & $440,395.0$ & $3,671,003.5$ & 59.7 \\
478 & $440,593.5$ & $3,671,000.0$ & 49.0 \\
479 & $440,516.9$ & $3,670,998.5$ & 50.5 \\
480 & $440,848.7$ & $3,670,998.1$ & 48.9 \\
481 & $440,875.2$ & $3,670,992.4$ & 49.4 \\
482 & $440,387.4$ & $3,670,950.2$ & 59.9 \\
483 & $440,535.5$ & $3,670,959.0$ & 47.0 \\
484 & $440,455.0$ & $3,670,941.5$ & 49.5 \\
485 & $440,472.7$ & $3,670,953.5$ & 48.0 \\
486 & $440,566.4$ & $3,670,949.8$ & 47.2 \\
\hline & & &
\end{tabular}


Table D-3. Location and Elevations of Ash Piles (continued)

\begin{tabular}{|c|c|c|c|}
\hline $\begin{array}{c}\text { Pile } \\
\text { ID No. }\end{array}$ & $\begin{array}{c}\text { Easting } \\
\text { UTM }\end{array}$ & $\begin{array}{c}\text { Northing } \\
\text { UTM }\end{array}$ & $\begin{array}{c}\text { Elevation } \\
\text { NAD27 }\end{array}$ \\
\hline 487 & $440,361.3$ & $3,670,946.0$ & 60.6 \\
\hline 488 & $440,480.2$ & $3,670,945.3$ & 46.7 \\
\hline 489 & $440,573.5$ & $3,670,918.4$ & 45.6 \\
\hline 490 & $440,983.5$ & $3,670,930.8$ & 56.9 \\
\hline 491 & $440,755.4$ & $3,670,914.7$ & 44.2 \\
\hline 492 & $440,440.6$ & $3,670,912.5$ & 50.3 \\
\hline 493 & $440,857.6$ & $3,670,890.2$ & 46.9 \\
\hline 494 & $440,459.3$ & $3,670,871.9$ & 46.5 \\
\hline 495 & $440,369.9$ & $3,670,864.8$ & 57.7 \\
\hline 496 & $440,427.1$ & $3,670,849.1$ & 50.8 \\
\hline 497 & $440,494.3$ & $3,670,850.6$ & 46.1 \\
\hline 498 & $440,341.3$ & $3,670,850.2$ & 58.8 \\
\hline 499 & $440,746.4$ & $3,670,848.4$ & 42.1 \\
\hline 500 & $440,842.2$ & $3,670,837.8$ & 45.9 \\
\hline 501 & $440,522.8$ & $3,670,824.6$ & 43.8 \\
\hline 502 & $440,552.8$ & $3,670,825.7$ & 42.2 \\
\hline 503 & $440,822.2$ & $3,670,824.9$ & 45.9 \\
\hline 504 & $440,444.2$ & $3,670,818.2$ & 49.3 \\
\hline 505 & $440,544.5$ & $3,670,803.2$ & 43.0 \\
\hline 506 & $440,339.4$ & $3,670,800.2$ & 56.6 \\
\hline 507 & $440,948.2$ & $3,670,770.0$ & 56.7 \\
\hline 508 & $440,557.6$ & $3,670,756.4$ & 43.5 \\
\hline 509 & $440,407.0$ & $3,670,746.8$ & 52.0 \\
\hline 510 & $440,750.8$ & $3,670,671.8$ & 49.7 \\
\hline 511 & $440,536.5$ & $3,670,640.0$ & 48.6 \\
\hline 512 & $440,880.3$ & $3,670,619.2$ & 56.9 \\
\hline 513 & $440,818.2$ & $3,670,609.7$ & 52.6 \\
\hline 514 & $440,507.4$ & $3,670,610.8$ & 48.6 \\
\hline 515 & $440,792.7$ & $3,670,603.0$ & 49.7 \\
\hline 516 & $440,464.8$ & $3,670,602.1$ & 49.7 \\
\hline 517 & $440,776.6$ & $3,670,507.3$ & 48.8 \\
\hline 518 & $440,508.5$ & $3,670,500.5$ & 49.4 \\
\hline 519 & $440,754.1$ & $3,670,486.6$ & 47.5 \\
\hline
\end{tabular}


Table D-3. Location and Elevations of Ash Piles (continued)

\begin{tabular}{c|c|c|c}
\hline $\begin{array}{c}\text { Pile } \\
\text { ID No. }\end{array}$ & $\begin{array}{c}\text { Easting } \\
\text { UTM }\end{array}$ & $\begin{array}{c}\text { Northing } \\
\text { UTM }\end{array}$ & $\begin{array}{c}\text { Elevation } \\
\text { NAD27 }\end{array}$ \\
\hline 520 & $440,456.8$ & $3,670,468.5$ & 51.5 \\
521 & $440,495.3$ & $3,670,453.6$ & 48.2 \\
522 & $440,771.1$ & $3,670,421.3$ & 48.9 \\
523 & $440,516.0$ & $3,670,420.5$ & 47.5 \\
524 & $440,916.9$ & $3,670,409.0$ & 56.7 \\
525 & $440,446.5$ & $3,670,419.3$ & 51.7 \\
526 & $440,863.2$ & $3,670,401.2$ & 49.7 \\
527 & $440,440.1$ & $3,670,378.8$ & 52.5 \\
528 & $440,867.0$ & $3,670,348.7$ & 52.8 \\
529 & $440,899.7$ & $3,670,335.0$ & 56.1 \\
530 & $440,830.2$ & $3,670,352.2$ & 49.0 \\
531 & $440,786.1$ & $3,670,328.3$ & 48.1 \\
532 & $440,831.3$ & $3,670,310.2$ & 49.6 \\
533 & $440,855.5$ & $3,670,305.9$ & 53.2 \\
534 & $440,350.0$ & $3,670,287.9$ & 55.0 \\
535 & $440,824.4$ & $3,670,282.2$ & 46.8 \\
536 & $440,856.9$ & $3,670,277.6$ & 53.7 \\
537 & $440,351.2$ & $3,670,255.7$ & 53.8 \\
538 & $440,868.6$ & $3,670,252.9$ & 56.4 \\
539 & $440,781.1$ & $3,670,225.1$ & 49.7 \\
540 & $440,442.7$ & $3,670,198.3$ & 46.9 \\
541 & $441,476.3$ & $3,670,212.0$ & 59.1 \\
542 & $441,451.8$ & $3,670,202.0$ & 58.1 \\
543 & $441,339.1$ & $3,670,192.5$ & 55.7 \\
544 & $440,397.3$ & $3,670,189.1$ & 49.6 \\
545 & $441,138.1$ & $3,670,175.4$ & 51.8 \\
546 & $441,158.8$ & $3,670,174.2$ & 51.2 \\
547 & $441,193.5$ & $3,670,174.6$ & 52.6 \\
548 & $441,371.0$ & $3,670,164.6$ & 55.3 \\
549 & $441,434.9$ & $3,670,166.8$ & 57.3 \\
550 & $441,101.7$ & $3,670,167.1$ & 53.1 \\
551 & $441,348.2$ & $3,670,164.2$ & 54.5 \\
552 & $441,234.0$ & $3,670,151.7$ & 52.0 \\
\hline & & &
\end{tabular}


Table D-3. Location and Elevations of Ash Piles (continued)

\begin{tabular}{c|c|c|c}
\hline $\begin{array}{c}\text { Pile } \\
\text { ID No. }\end{array}$ & $\begin{array}{c}\text { Easting } \\
\text { UTM }\end{array}$ & $\begin{array}{c}\text { Northing } \\
\text { UTM }\end{array}$ & $\begin{array}{c}\text { Elevation } \\
\text { NAD27 }\end{array}$ \\
\hline 553 & $441,072.7$ & $3,670,147.2$ & 52.4 \\
554 & $441,299.9$ & $3,670,115.0$ & 55.0 \\
555 & $441,190.4$ & $3,670,110.3$ & 51.5 \\
556 & $441,433.5$ & $3,670,110.7$ & 60.3 \\
557 & $441,243.0$ & $3,670,097.2$ & 53.2 \\
558 & $441,053.4$ & $3,670,075.3$ & 48.1 \\
559 & $441,197.5$ & $3,670,079.4$ & 53.2 \\
560 & $440,431.7$ & $3,670,061.8$ & 47.9 \\
561 & $441,168.7$ & $3,670,032.7$ & 53.7 \\
562 & $441,243.2$ & $3,670,025.4$ & 56.7 \\
563 & $441,128.7$ & $3,670,023.1$ & 50.7 \\
564 & $441,314.7$ & $3,669,992.4$ & 58.8 \\
565 & $441,327.2$ & $3,669,956.0$ & 59.6 \\
566 & $441,169.5$ & $3,669,948.0$ & 57.6 \\
567 & $440,879.6$ & $3,669,909.1$ & 46.6 \\
568 & $440,821.1$ & $3,669,885.7$ & 48.7 \\
569 & $440,867.9$ & $3,669,878.0$ & 46.6 \\
570 & $440,896.0$ & $3,669,852.2$ & 45.7 \\
571 & $440,815.0$ & $3,669,861.0$ & 48.2 \\
572 & $440,819.2$ & $3,669,834.0$ & 48.6 \\
573 & $440,897.6$ & $3,669,807.0$ & 46.0 \\
574 & $441,262.8$ & $3,669,803.4$ & 58.2 \\
575 & $440,844.8$ & $3,669,795.7$ & 47.4 \\
576 & $440,862.3$ & $3,669,775.2$ & 46.5 \\
577 & $441,327.9$ & $3,669,779.9$ & 60.4 \\
578 & $440,871.1$ & $3,669,755.4$ & 45.2 \\
579 & $441,317.3$ & $3,669,694.2$ & 58.5 \\
580 & $441,333.8$ & $3,669,678.7$ & 59.0 \\
& $441,209.5$ & $3,669,660.8$ & 47.3 \\
582 & $441,192.0$ & $3,669,616.1$ & 46.9 \\
583 & $441,294.9$ & $3,669,583.7$ & 57.7 \\
$541,326.7$ & $3,670,156.9$ & 54.1 \\
\hline 5 & &
\end{tabular}


Table D-4. Location and Elevations of Potential Waste Units

\begin{tabular}{c|c|c|c}
\hline $\begin{array}{c}\text { Unit } \\
\text { ID No. }\end{array}$ & $\begin{array}{c}\text { Easting } \\
\text { UTM }\end{array}$ & $\begin{array}{c}\text { Northing } \\
\text { UTM }\end{array}$ & $\begin{array}{c}\text { Elevation } \\
\text { NAD27 }\end{array}$ \\
\hline 9 & $441,134.7$ & $3,669,895.8$ & 57.3 \\
10 & $440,916.8$ & $3,670,896.3$ & 49.2 \\
11 & $441,096.1$ & $3,672,570.1$ & 58.1 \\
31 & $440,959.7$ & $3,670,149.2$ & 50.1 \\
51 & $441,196.6$ & $3,669,572.1$ & 53.7 \\
54 & $441,245.1$ & $3,669,896.3$ & 59.1 \\
55 & $441,018.1$ & $3,669,694.4$ & 45.4 \\
56 & $441,099.4$ & $3,669,762.0$ & 52.9 \\
60 & $440,485.6$ & $3,669,877.8$ & 55.1 \\
62 & $440,681.8$ & $3,669,385.9$ & 53.4 \\
63 & $440,578.0$ & $3,669,586.1$ & 57.2 \\
\hline
\end{tabular}

Table D-5. Location and Elevations of Debris Piles

\begin{tabular}{c|c|c|c}
\hline $\begin{array}{c}\text { Pile } \\
\text { ID No. }\end{array}$ & $\begin{array}{c}\text { Easting } \\
\text { UTM }\end{array}$ & $\begin{array}{c}\text { Northing } \\
\text { UTM }\end{array}$ & $\begin{array}{c}\text { Elevation } \\
\text { NAD27 }\end{array}$ \\
\hline 2 & $441,191.1$ & $3,672,684.7$ & 59.3 \\
3 & $440,827.3$ & $3,670,602.1$ & 53.8 \\
4 & $440,400.5$ & $3,672,171.1$ & 55.9 \\
5 & $441,051.1$ & $3,671,253.7$ & 55.9 \\
6 & $440,841.7$ & $3,672,854.4$ & 58.8 \\
7 & $440,822.1$ & $3,672,248.2$ & 54.9 \\
8 & $440,843.6$ & $3,672,350.4$ & 55.5 \\
9 & $440,310.9$ & $3,671,293.7$ & 58.4 \\
10 & $440,381.2$ & $3,671,009.8$ & 61.0 \\
11 & $441,203.9$ & $3,671,891.7$ & 56.2 \\
12 & $441,137.9$ & $3,670,214.0$ & 56.2 \\
13 & $440,379.2$ & $3,669,856.4$ & 60.5 \\
14 & $440,340.3$ & $3,670,380.2$ & 58.2 \\
\hline
\end{tabular}


Table D-6. Location and Elevations of Borrow Pits

\begin{tabular}{c|c|c|c}
\hline $\begin{array}{c}\text { Pit } \\
\text { ID No. }\end{array}$ & $\begin{array}{c}\text { Easting } \\
\text { UTM }\end{array}$ & $\begin{array}{c}\text { Northing } \\
\text { UTM }\end{array}$ & $\begin{array}{c}\text { Elevation } \\
\text { NAD27 }\end{array}$ \\
\hline 1 & $441,565.0$ & $3,673,381.8$ & 53.9 \\
2 & $440,811.0$ & $3,669,448.2$ & 48.5 \\
3 & $440,506.9$ & $3,669,463.5$ & 59.1 \\
4 & $440,858.2$ & $3,671,575.3$ & 49.3 \\
\hline
\end{tabular}

Table D-7. Location and Elevations of Fish Structures

\begin{tabular}{|c|c|c|c|}
\hline $\begin{array}{l}\text { Structure } \\
\text { ID No. }\end{array}$ & $\begin{array}{c}\text { Easting } \\
\text { UTM }\end{array}$ & $\begin{array}{c}\text { Northing } \\
\text { UTM }\end{array}$ & $\begin{array}{c}\text { Elevation } \\
\text { NAD27 }\end{array}$ \\
\hline 7 & $440,257.2$ & $3,669,873.6$ & 61.2 \\
\hline 8 & $440,231.1$ & $3,669,891.1$ & 59.4 \\
\hline 9 & $440,221.2$ & $3,669,924.4$ & 59.6 \\
\hline 10 & $440,225.1$ & $3,669,943.9$ & 61.6 \\
\hline 11 & $440,222.2$ & $3,669,951.9$ & 65.7 \\
\hline 12 & $440,308.7$ & $3,670,061.3$ & 59.6 \\
\hline 13 & $440,321.0$ & $3,670,130.9$ & 58.9 \\
\hline 14 & $440,319.9$ & $3,670,149.6$ & 58.4 \\
\hline 15 & $440,314.4$ & $3,670,166.9$ & 58.4 \\
\hline 16 & $440,312.4$ & $3,670,183.6$ & 58.2 \\
\hline 17 & $440,308.4$ & $3,670,197.9$ & 58.7 \\
\hline 18 & $440,290.9$ & $3,670,333.6$ & 59.7 \\
\hline 19 & $440,373.6$ & $3,670,767.2$ & 55.0 \\
\hline 20 & $440,354.7$ & $3,670,763.8$ & 55.1 \\
\hline 21 & $440,371.5$ & $3,670,785.7$ & 54.9 \\
\hline 22 & $440,361.3$ & $3,670,775.1$ & 54.8 \\
\hline 23 & $440,345.2$ & $3,670,781.6$ & 55.9 \\
\hline 25 & $440,440.6$ & $3,671,114.5$ & 56.1 \\
\hline 27 & $441,010.2$ & $3,671,196.2$ & 56.9 \\
\hline 27 & $440,828.9$ & $3,670,601.7$ & 54.1 \\
\hline 28 & $440,906.4$ & $3,670,789.8$ & 54.5 \\
\hline 29 & $440,927.0$ & $3,670,375.2$ & 57.9 \\
\hline 30 & $441,038.7$ & $3,670,215.4$ & 56.4 \\
\hline 31 & $441,187.0$ & $3,670,232.1$ & 57.1 \\
\hline
\end{tabular}


Table D-7. Location and Elevations of Fish Structures (continued)

\begin{tabular}{c|c|c|c}
\hline $\begin{array}{c}\text { Structure } \\
\text { ID No. }\end{array}$ & $\begin{array}{c}\text { Easting } \\
\text { UTM }\end{array}$ & $\begin{array}{c}\text { Northing } \\
\text { UTM }\end{array}$ & $\begin{array}{c}\text { Elevation } \\
\text { NAD27 }\end{array}$ \\
\hline 32 & $441,178.7$ & $3,670,225.4$ & 56.8 \\
34 & $441,229.0$ & $3,669,715.9$ & 54.9 \\
35 & $441,237.2$ & $3,669,698.4$ & 54.5 \\
\hline
\end{tabular}




\section{REFERENCES}

Briese, L.A., C.T. Garten, Jr., and R.R. Sharitz. "Distribution of Radiocesium in Vegetation Along a Contaminated Stream," Mineral Cycling in Southeastern Ecosystems. USAEC Symposium Series, CONF-740513, 1975; pp 509-517.

Brisbin, I.L., Jr., R.J. Beyers, R.W. Dapson, R.A. Geiger, J.B. Gentry, J.W. Gibbons, M.H. Smith, and S.K. Woods. "Patterns of Radiocesium in the Sediments of a Stream Channel Contaminated by Production Reactor Effluents." Health Physics. 1974; 27:19-27.

Carlton, W.H., L.R. Bauer, A.G. Evans, L.A. Geary, C.E. Murphy, Jr., J.E. Pinder, and R.N. Strom. Cesium in the Savannah River Site Environment. WSRC-RP-92-250, Westinghouse Savannah River Company, Savannah River Site, Aiken, South Carolina, 1992.

Carlton, W.H., and M. Denham. Assessment of Activation Products in the Savannah River Site Environment. WSRC-TR-95-0422, Westinghouse Savannah River Company, Aiken, South Carolina, 1996.

Dunn, D.L., W.G. Winn, and P.J. Bresnahan. Scoping Measurements of Radionuclides in L Lake with an Underwater HPGe Detector (U). WSRC-TR-95-0397, Westinghouse Savannah River Company, Savannah River Site, Aiken, South Carolina, 1995.

ERDAS, Inc. ERDAS Imagine, Version 8.2. Atlanta, Georgia, 1995.

ESRI, ARC/INFO Version 7.0.4, Redlands, California, 1996.

Ezra, C.E., and L.R. Tinney. Steel Creek Land Cover Data Base, Savannah River Plant, Aiken, South Carolina. EG\&G/EM Letter Report DOE/ONS-8510, EG\&G/EM, Las Vegas, Nevada, 1985.

Gladden, J.B., K.L. Brown, M.H. Smith, and A. Towns. "Distribution of Gamma Exposure Rates in a Reactor Effluent Stream Flood Plain System." Health Physics. 1985; 48:49-59.

Gladden, J.B., W.L. Specht, J.A. Bowers, N.V. Halverson, H.E. Mackey, and E.W. Wilde. Compliance of the Savannah River Plant L-Reactor Cooling System with Environmental Regulations (U)-Demonstration in Accordance with Section 316(a) of the Clean Water Act, November 1985-December 1987. DP-1766, Rev. 1, E.I. du Pont de Nemours \& Co., Savannah River Laboratory, Aiken, South Carolina, 1989.

McCort, W.D., L.C. Lee, and G.R. Wein. "Mitigating for Large-Scale Wetland Loss: A Realistic Endeavor?" In: J.A. Kusler, M.L. Quammen, and G. Brooks (eds.). Proceedings of the National Wetland Symposium: Mitigation of Impacts and Losses. Association of State Wetland Managers, Inc. 1988; pp 359-367.

Savannah River Plant [Topographic]. Augusta, Georgia: Baldwin and Cranston Associates, Inc,; 1984 September (Cooling Reservior, "L" Area, Savannah River Site; [sheet] ST 1-4).

Sharitz, R.R., S.L. Scott, J.E. Pinder, III, and S.K. Woods. "Uptake of Radiocesium from Contaminated Floodplain Sediment by Herbaceous Plants." Health Physics. 1974; 28:23-28.

Tinney, L.R., C.E. Ezra, and H.E. Mackey, Jr. Stream Corridor and Delta Wetlands Change Assessment, Savannah River Plant, Aiken, South Carolina. Report No. DOE (ONS-SRL)-8604, EG\&G/EM, Las Vegas, Nevada, 1986; p 55. 
U.S. Department of Energy. Final Environmental Impact Statement. L-Reactor Operation Savannah River Plant, Aiken, S.C. DOE/EIS-0108. 1984; Volumes 1-13,

U.S. Geological Survey. 7.5 Minute Series (Topographic). Reston, VA, 1964.

Vision International, Inc. SoftPlotter User's Manual, Version 1.6.. Earth City, MO, 1996

Wein, G.R., and W.D. McCort. "Sources of Complexity in Wetland Mitigation." In: J. Zelazny and J. S. Feierbend (eds.). Proceedings of Wetlands: Increasing Our Wetland Resources. October 4-7, 1987. Washington, D.C. National Wildlife Federation-Corporate Conservation Council, 1988; pp. 41-50.

Wein, G.R., and G. Pierce. "Case Study \#1: L-Lake, Savannah River Plant, South Carolina," In: Native Plant Material Sources for Wetland Establishment: Freshwater Case Studies. Technical Report WRP-RE-5, U.S. Army Corps of Engineers, Waterways Experiment Station, Vicksburg, MS, 1995; pp 13-35.

Zeigler, C.C., I.B. Lawrimore, and W.E. O'Rear. Environmental Monitoring at the Savannah River Plant, Annual Report-1984. DPSPU 85-302, Health Protection Department, Savannah River Plant, E. I. du Pont de Nemours and Company, Aiken, South Carolina, 1985. 
DOE/DP

L. E. Gordon-Hagerty

(1)

(1)

(1)

(1)

(10)

(1)

(1)

(5)

(2)

(10)

SRS/WSRC

D. L. Dunn

H. E. Mackey
SRS/WSRC (continued)

B. Marcy

D. B. Moore-Shedrow

W. G. Winn

BN

R. G. Best LVAO (1)

J. D. Blohm LVAO (1)

L. M. Christel LVAO (1)

P. P. Guss WAMO (1)

R. E. Kelley LVAO

(1)

K. R. Lamison LVAO

J. T. Mitchell LVAO

L. G. Sasso LVAO

(1)

\section{LIBRARIES}

RSL

(30)

OSTI

\author{
)
}

